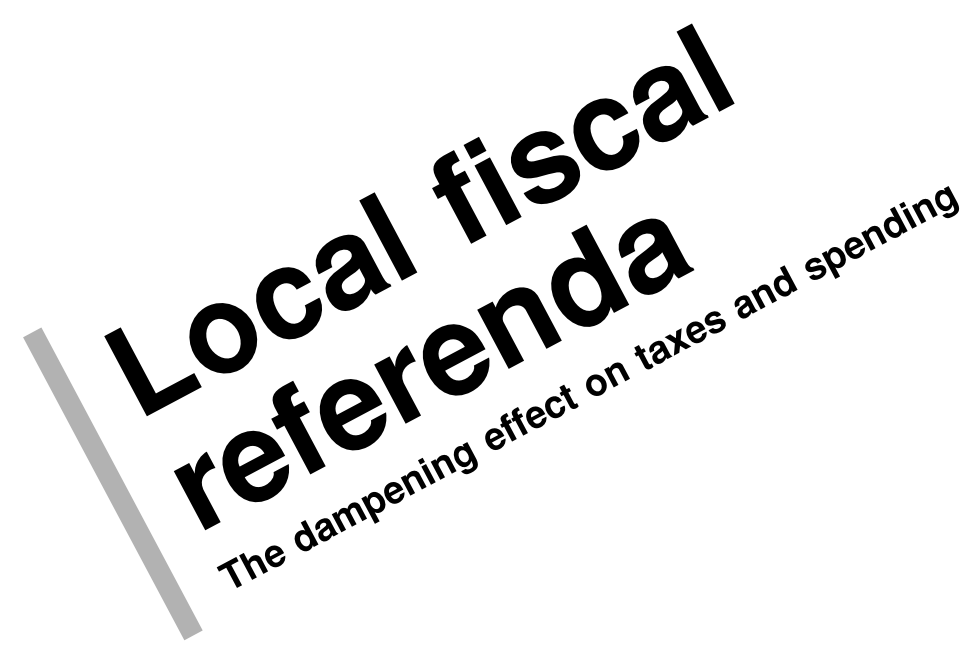

\title{
SUMMARY
}

Local and regional governments account for an important share of total government spending and, given the decentralization trend in OECD nations, this is likely to increase. How should this spending be governed? This article argues that direct democracy is best suited to organize decision-making at the state and local level. To support this, we present the main theoretical arguments on why and how referenda and initiatives affect fiscal policy outcomes. The basic argument concerns voter control. Under representative democracy, citizens only have direct control at election time. With referenda and initiatives, citizens can selectively control their representatives on specific policies whenever they deviate sufficiently from citizens' preferences. As a result, fiscal policy outcomes are likely to more closely reflect voter preferences. We empirically test this on Swiss data since Switzerland provides a 'natural laboratory' for local governance. The governance structures of Swiss cantons and localities with respect to fiscal issues range from classic parliamentary democracy to pure direct democracy, and an important part of spending and taxation is controlled at these levels. Specifically, we estimate an econometric model of fiscal behaviour using data from 1986 to 1997 for the 26 Swiss cantons, and 1990 data on 134 local communities. It is shown that mandatory referenda on fiscal issues at both levels have a dampening effect on expenditure and revenue, and at the local level also on public debt. Combining this with existing empirical evidence leads to a relatively uncontested result, namely that elements of direct democracy are associated with sounder public finances, better economic performance and higher satisfaction of citizens.

— Lars P. Feld and Gebhard Kirchgässner 


\section{The political economy of direct legislation: direct democracy and local decision-making}

\section{Lars P. Feld and Gebhard Kirchgässner}

Universität St Gallen and Swiss Institute for International Economics and Applied Economic Research (SIAW-HSG)

\section{INTRODUCTION}

Direct democracy is gaining momentum at the local and regional level just as many OECD nations are decentralizing decision-making, especially fiscal decisions, to subnational levels of government.

In the US, local and state-level initiatives and referenda are increasingly common. The state of Mississippi introduced popular initiatives in its constitution in 1993, and similar moves are being considered in New Jersey, Rhode Island and Texas. In California, the US state in which initiatives are most frequently used, 49 initiatives were already held from 1990 to 1996 while only nine initiatives were held in the 1960s. Similar moves have also been made in Europe. At the German state and local levels, the hurdles to use direct legislation in the form of signature requirements and quorums - have been significantly reduced since 1989. The Netherlands has also discussed the introduction of direct democracy at the local level. ${ }^{1}$ The Economist summed up this trend in its recent survey on democracy:

'the next big change in human affairs will probably not be a matter of economics, or electronics, or military science; it will be a change in the supposedly humdrum world

\footnotetext{
The authors would like to thank Richard Baldwin, Kai Konrad, Michael Lechner, Jan van Ours, Christoph Schaltegger, Jean-Robert Tyran, Thierry Verdier and the participants of the 33rd Economic Policy Panel Meeting at the Stockholm School of Economics for helpful suggestions and discussions.

${ }^{1}$ See Heussner (1999), and Heussner and Jung (1999) for more details on the US and Germany. See Butler and Ranney (1994) for an extensive account of the different systems in OECD nations.
} 
of politics. The coming century could see, at last, the full flowering of the idea of democracy ... If democracy means rule by the people, democracy by referendum is a great deal closer to the original idea than the every-few-years voting which is all that most countries have'. ${ }^{2}$

Proposals for more direct democracy, however, have not been limited to local government.

The general secretary of the German Social Democrats, for example, advocates referenda and initiatives at the German federal level (Müntefering, 2000), and quite a number of the post-Communist constitutions in Eastern Europe include the right of initiatives and referenda (White and Hill, 1996). In Switzerland, which is often considered as the cradle of direct democracy, more initiatives and referenda are held at the Swiss state (cantonal) and local levels than at the federal level, but the number of federal-level referenda and initiatives has steadily increased from 21 in total in the $1930 \mathrm{~s}$ to 90 in total in the 1990s. The Danish and Irish referenda on the participation in EU integration are widely debated and respected in the other EU member states, and the EU Commissioner for External Affairs, Günter Verheugen, even proposed an EU-wide referendum on Eastern Enlargement.

This re-thinking of centralization is also a key issue in the EU. The Intergovernmental Conference to be held in 2004, for example, is supposed to decide on a consolidated assignment of competencies to the different government levels in the EU. This development may end up in a constitutional proposal for a federal EU creating a European government and a two chamber system including additional budgetary rights like own taxation power for the Parliament. Another potential issue for a European constitution is the role of the regional and local levels in EU and national decisionmaking. This role is sometimes referred to in the context of a 'Europe of the Regions' meaning - in its extreme form - that some regions, like Corsica or Lombardy, may secede from France and Italy, respectively, and become a member of the EU as a region (Drèze, 1993). Besides all the problems secessions and the current advisory status of the Committee of the Regions might pose to the EU and the different member states, the discussions on a Europe of the Regions underline the necessity of having a closer look on how regional and local governments in Europe are organized.

\subsection{Decentralization}

This development in democratic decision-making at different government levels has been paralleled by another development in OECD countries, the decentralization of competencies. Major decentralization took place in France in 1986 with the creation of the regions, a reform that was accompanied by granting more competencies to the subfederal levels in particular with respect to fiscal issues. Belgium, Spain and Italy are still in

${ }^{2}$ Cited from: 'Full democracy: It means government by the people and we are the people', in A Survey of Democracy: Happy 21 st Century Voters, The Economist, 21 December 1996. 
the process of decentralizing, and the newly elected Italian Prime Minister Silvio Berlusconi seems to favour greater federalism for Italy. The United Kingdom has also decentralized governance with the creation of the Scottish and Welsh parliaments. Finally, after a long period of centralization, there is discussion of revitalizing federalism in some traditionally federalist OEGD countries - e.g., Switzerland, USA, Canada, Germany, Australia and Austria. ${ }^{3}$ The main thrust of the political reforms and reform proposals concerns the assignment of competencies, in particular of fiscal competencies.

An issue seldom discussed in this context is how state and local governance should be organized. The development towards direct democratic decision-making at the regional and local levels seems to take place independently from the development of decentralization. The more important regional and local jurisdictions are in the internal organization of a nation-state, the more important is the question of the proper decisionmaking procedures at the different government levels. The assignment of competencies to different government levels is linked to decision-making procedures. This holds in political as well as economic terms, though the main interest of economists in this respect is the consequences that different decision-making structures have for economic policy in general and for fiscal issues in particular.

This paper analyses the impact of direct democracy on public expenditure, revenue, deficits and debt, paying special attention to how the precise form of direct democracy matters (e.g., whether fiscal issues are decided in referenda or initiatives). We argue that institutions of direct democracy are best suited to organize state and local decision-making, particularly with respect to fiscal issues. Our argument is based on theoretical arguments that illustrate why referenda and initiatives are useful supplements to representative democracy, and on empirical evidence from Switzerland and the US. The central theoretical argument is that direct democracy provides citizens with the means of selectively controlling their representatives on specific policy questions when such policies deviate sufficiently far from citizens' preferences. This theory is then backed up by empirical evidence. Taking up earlier results for Switzerland, we study the impact of fiscal referenda and statutory initiatives on public revenue, public spending, budget deficits and public debt in Switzerland; we first consider the impact of mandatory fiscal referenda and initiatives on cantonal fiscal policies for data on 26 Swiss cantons from 1986 to 1997, before turning to the impact of referenda on new bonds and of budgetary procedures on local fiscal policies using a cross section of 134 large (including the largest) Swiss cities. This combination of theory and evidence leads us to the proposal that referenda and initiatives should be introduced at the sub-federal levels in EU member states.

\subsection{Structure of the paper}

In Section 2 evidence is given on the quantitative importance of the state and local fiscal policy in 13 OECD countries. The next section briefly introduces the reader to different

${ }^{3}$ See Blankart (2000) for a comparative analysis of centralization in Germany and Switzerland. 
forms of governance at sub-federal levels. Section 4 explains how and why one should expect local direct democracy to affect fiscal outcomes. This involves a survey of the main theoretical arguments. In Section 5, we offer an econometric model for the empirical analysis of the impact of direct democracy on public spending, revenue and deficits and present the empirical results. The results are put into perspective by discussing them in the context of existing empirical results followed by a policy proposal to introduce direct democracy at the sub-federal levels in EU member countries in Section 6. Finally, we offer some concluding remarks in Section 7. Further detail on the empirical aspects of this paper can be found in the Web Appendix for this article (available at www.economic-policy.org).

\section{THE IMPORTANCE OF STATE AND LOCAL FISCAL POLICY}

Focusing on macroeconomic questions that are of importance mainly from a national government perspective often hides the fact that state and local governments in OECD countries have considerable competencies - even in countries that are not traditionally considered federalist (Switzerland, the US, Canada, Germany, Australia and Austria). As mentioned above, a growing decentralization can also be observed in other OECD countries, such as Spain, Italy and Belgium. In general it is difficult to measure the extent to which competencies are decentralized, but one set of indicators allows a direct quantification - the shares of total government revenue and spending that are accounted for by the central, state and local levels. Figures on this (for the year 1997) are presented in Table 1.

A first glance at Table 1 suggests that some OECD countries seem to have negligible or even zero state level spending. These countries are those that are traditionally thought of being centralist, like the UK, Sweden, the Netherlands, but also Italy and Belgium. The latter two countries have only recently introduced state levels or increased the importance of the regional levels, so the impact of these developments is not fully reflected in the Table 1 figures, which are for 1997. The federalist countries together with Spain exhibit different degrees of centralization in 1997 ranging from a low of $16.88 \%$ of state revenue (15.43\% for expenditure) in Austria to $44.45 \%$ of state revenue (42.40\% for expenditure) in Canada.

The range of local government competencies seems to be even more pronounced, ranging from $5.3 \%$ for local revenue in the case of Australia to $34.4 \%$ in Sweden. In absolute terms, the figures in Table 1 mean, for example, that US states spent about $\$ 850$ billion and US local jurisdictions about $\$ 710$ billion while the German Länder spent about $\$ 240$ billion in 1997 . These figures plainly illustrate the importance of state and local fiscal policy in quantitative terms, but it is worth looking at these numbers more closely.

\subsection{Refining the numbers}

The distribution of spending and revenue shares among the different government levels, however, is only a proxy for the assignment of competencies. The share of revenue 
Table 1. Central, state and local revenue and expenditure as a percentage of total expenditure and revenue, 13 OECD countries, 1997

\begin{tabular}{|c|c|c|c|c|c|c|}
\hline & \multicolumn{3}{|c|}{ Revenue } & \multicolumn{3}{|c|}{ Expenditure } \\
\hline & $\begin{array}{c}\text { Central } \\
\text { Government }\end{array}$ & $\begin{array}{c}\text { State } \\
\text { Government }\end{array}$ & $\begin{array}{c}\text { Local } \\
\text { Government }\end{array}$ & $\begin{array}{c}\text { Central } \\
\text { Government }\end{array}$ & $\begin{array}{c}\text { State } \\
\text { Government }\end{array}$ & $\begin{array}{c}\text { Local } \\
\text { Government }\end{array}$ \\
\hline Australia & $\begin{array}{c}58.61 \\
(68.52)\end{array}$ & $\begin{array}{c}36.09 \\
(26.29)\end{array}$ & $\begin{array}{c}5.30 \\
(5.19)\end{array}$ & 60.33 & 34.30 & 5.37 \\
\hline Austria & $\begin{array}{c}67.16 \\
(76.02)\end{array}$ & $\begin{array}{c}16.88 \\
(9.35)\end{array}$ & $\begin{array}{c}15.96 \\
(14.63)\end{array}$ & 69.39 & 15.43 & 15.18 \\
\hline Belgium & $\begin{array}{c}88.14 \\
(93.96)\end{array}$ & - & $\begin{array}{l}11.86 \\
(6.04)\end{array}$ & 89.15 & - & 10.85 \\
\hline Canada & $\begin{array}{c}38.20 \\
(45.25)\end{array}$ & $\begin{array}{c}44.45 \\
(43.58)\end{array}$ & $\begin{array}{c}17.35 \\
(11.18)\end{array}$ & 41.89 & 42.40 & 15.70 \\
\hline France & $\begin{array}{c}81.00 \\
(86.45)\end{array}$ & - & $\begin{array}{c}19.00 \\
(13.55)\end{array}$ & 82.54 & - & 17.46 \\
\hline Germany & $\begin{array}{c}60.72 \\
(67.07)\end{array}$ & $\begin{array}{c}23.08 \\
(20.69)\end{array}$ & $\begin{array}{c}16.20 \\
(12.24)\end{array}$ & 60.11 & 24.10 & 15.79 \\
\hline Italy & $\begin{array}{c}78.09 \\
(90.92)\end{array}$ & - & $\begin{array}{c}21.91 \\
(9.08)\end{array}$ & 78.00 & - & 22.00 \\
\hline Netherlands & $\begin{array}{c}75.20 \\
(90.49)\end{array}$ & - & $\begin{array}{c}24.80 \\
(9.51)\end{array}$ & 78.29 & - & 21.71 \\
\hline Spain & $\begin{array}{c}66.28 \\
(83.18)\end{array}$ & $\begin{array}{l}20.38 \\
(5.77)\end{array}$ & $\begin{array}{c}13.34 \\
(11.04)\end{array}$ & 69.02 & 19.32 & 11.66 \\
\hline Sweden & $\begin{array}{c}65.60 \\
(68.84)\end{array}$ & - & $\begin{array}{c}34.40 \\
(31.16)\end{array}$ & 65.63 & - & 34.37 \\
\hline Switzerland & $\begin{array}{c}52.34 \\
(56.79)\end{array}$ & $\begin{array}{c}27.72 \\
(22.91)\end{array}$ & $\begin{array}{c}19.94 \\
(20.30)\end{array}$ & 52.69 & 27.79 & 19.52 \\
\hline United Kingdom & $\begin{array}{l}77.06 \\
(92.31)\end{array}$ & - & $\begin{array}{r}22.94 \\
(7.69)\end{array}$ & 78.09 & - & 21.91 \\
\hline United States & $\begin{array}{c}50.00 \\
(58.39)\end{array}$ & $\begin{array}{c}28.48 \\
(25.93)\end{array}$ & $\begin{array}{c}21.51 \\
(15.68)\end{array}$ & 52.16 & 26.09 & 21.75 \\
\hline
\end{tabular}

Notes: Numbers in parentheses are the shares of revenue excluding grants and thus excluding double counting. Expenditure figures are without considering lending and repayment. A dash (-) means that no data are available.

Sources: Own calculations from IMF, Government Finance Statistics Yearbook 1999, Washington DC, 2000. Data are for 1997 except for Canada (1995) and Spain (1996). Local government share for the Netherlands is the share of state and local revenue and expenditure.

allocated to the state level might be the result of a high amount of grants spent by the federal level. In addition, several tax-sharing arrangements exist in which the sub-federal levels have only a reduced decision-making power on the final tax burden of citizens. In Australia, Austria and Germany, revenue from the most important taxes, personal and corporate income and value added taxes, is shared among the different government levels. Finally, many spending programmes are determined by federal mandates such that the discretion of sub-federal governments in the determination of public services is strongly reduced.

2.1.1. Netting out revenue grants. To account for grants, we calculate revenue shares net of grants. The figures, shown in parentheses in Table 1, reveal notable differences. The share of local revenue considerably declines in the case of Italy, the Netherlands and the UK indicating that the local jurisdictions of these countries do not possess strong 
taxation competencies. This is different for the US and Switzerland where sub-federal governments have a similar weight with and without grants.

2.1.2. Tax-setting powers. Additional insights can be obtained from the analysis undertaken by OECD (1999). This study investigated the extent to which state and local jurisdictions can determine tax rates and bases independently from superior government levels. Feld and Schneider (2001) summarize these investigations by stating that state and local jurisdictions in Switzerland, the US and Canada have the most independently determined tax policies, while local jurisdictions in Sweden have considerable independence mainly with respect to expenditure. The main difference between Switzerland and the two North American countries is the fact that income taxes are mainly collected at the Swiss cantonal and local levels, while in Canada and the US, state revenue relies more heavily on indirect (sales) taxes.

As concerns our argument, there are three main conclusions. First, state and local governments have important roles in fiscal policy. Second, state and local taxing and spending power is greater in federalist countries (Switzerland, the US, Canada, Germany, Australia and Austria) than it is in centralist countries; within the group of federalist countries, decentralization is more pronounced in the three countries that display separation of taxing powers (Switzerland, the US and Canada) than it is in the three countries with tax sharing for the most important taxes. Finally, the organization of governance at the different levels of government might indicate their independence to a different extent.

Having considered the quantitative importance of sub-federal decision-making, we turn next to consider the various forms of state and local government.

\section{DECISION-MAKING ON LOCAL FISCAL ISSUES}

\subsection{A typology of local government structures}

The vast range of sub-federal government structures may be stylized into three pure forms - pure administration, pure representative democracy and pure direct democracy. The pure administrative model is where regional or local officials are appointed by a superior administration. The pure representative democracy model involves an elected regional or local representative body that appoints the regional or local administration. Such bodies are controlled during their terms by the normal democratic rules and may be held responsible for its policy in coming elections. This pure form of regional or local representative democracy is not supplemented by any kind of direct democratic instrument. The third pure model is governance by direct democracy. In its unadulterated form, regional or local direct democracy means citizens vote on each political issue in town or regional meetings. Administrators are appointed in these meetings to administer the day-to-day issues of these polities, but their discretion in political decision-making is limited. 
Even the most casual inspection of reality shows that these pure forms are rarely applied in OECD countries at the local level. Rather, one observes combinations of two or three of these models. In addition, the models of governance might differ according to the political issue at hand, for example with respect to tax issues versus spending issues. Since direct democracy will be less familiar to most readers, we elaborate the major dimensions along which direct democracy mechanism differ (our empirical results discussed below show that these differences seem to influence economic outcomes). In keeping with the theme at hand, we concentrate on direct democratic control of local fiscal policy.

\subsubsection{Direct democracy in practice: initiatives and referenda. Direct democracy}

in its pure form of an assembly meeting is quite rare, with the exceptions being town meetings in the US and Switzerland. Today, elements of direct democracy, like referenda and initiatives, are typically introduced in conjunction with representative democracy making most direct democratic forms of governance hybrids. The reason for these hybrid systems is simply that it is impractical to hold votes on absolutely every local fiscal decision. The types of decisions to be put to a popular vote, or the procedures for determining this, are specified in local and state constitutions.

The system of mandatory referenda is the strongest form of direct democratic control since it requires that a referendum be held on all new fiscal decisions (e.g., spending projects). Yet even here, the representative part of democratic decision-making plays a role since local officials formulate the details of policy to be voted on. In Switzerland, for example, the system of mandatory referenda often includes a threshold rule, such that a referendum must be held only if the financial size of the project exceeds a certain level. Voters then approve or reject the project and, if rejected, officials have a chance to revise the proposal and resubmit it to another referendum. The major parameters in this system are the size of the project requiring voter approval, and the range of fiscal decisions requiring direct voter consent (tax changes, and debt issuances are two of the most important examples in addition to spending projects).

The system of optional referendum is similar. The difference is that voters can only force local officials to hold a referendum on a new spending proposal if they succeed in collecting a predetermined number of signatures from their fellow citizens. The major parameter in this system is the number of signatures required, and the range of policies that can be put to a vote.

Initiatives are the third major form of direct democracy. As its name suggests, this involves a policy initiative that comes directly from the citizens. Specifically, a group (or even an individual) formulates a policy and if the group can gather enough signatures from other citizens, the initiative is submitted to a referendum. If it is accepted, the policy must be implemented. The major parameter in this form of direct democracy is the number of signatures necessary to bring the issue to a vote. 


\subsection{Examples from France and Germany}

France provides an example of local governance in which sub-federal jurisdictions were used for administrative purposes. Before the decentralization that started in the beginning of the 1980s and culminated in the creation of regions in 1986, France had adopted a system of far-reaching sub-central administration in taxation issues. The leeway of elected regional and local representatives to change tax rates or bases was very narrow. In addition, tax administrators who were appointed by superior level governments collected tax revenue according to federal mandates. ${ }^{4}$ Nevertheless, there was some discretion for local policy-makers in setting the tax rates of local property taxes, in co-determining who was appointed to the local tax administration and in determining the level of several local public services.

Regional and local governance in Germany follows, to a large extent, the model of representative democracy. The elected officials at the German sub-federal levels have considerable discretion to determine the amount of regional and local public goods provided. There is also some possibility to change tax rates independently at the local level. However, in many cases, superior levels of government appoint the administrations controlling regional and local public services. Moreover, such public services may be fixed by federal mandates. On the other hand, there is currently a movement towards direct democratic governance in some German states (e.g., Bavaria, NorthrhineWestphalia and Thuringia).

In contrast to the French and German models, the provision for institutions of direct democracy in Switzerland enable citizens to directly intervene in daily politics to a large extent. Although Swiss sub-federal jurisdictions also exhibit hybrid forms of governance by having parliaments and appointed administrators like Germany or France, it is fair to say that Switzerland leans more strongly towards the direct democracy model of governance than any other European country.

\subsection{The Swiss 'laboratory’: local and cantonal fiscal policy decision-making}

We are particularly interested in the Swiss case for three reasons. First, an important part of Swiss spending and taxation is controlled at the local and cantonal level, so abundant data on fiscal outcomes is available. Second, the long history of local direct democracy provides relatively long data series and ensures that the interactions between voters and politicians are not evolving due to learning effects. Third, Switzerland provides something of a natural laboratory for local governance in that the Swiss cantons and localities display an impressive range of local governance structures - a range that spans all three pure forms.

Most of the Swiss cantons have representative democracy in the form of a parliament. There are, however, two notable exceptions that still use a type of 'town meeting' form of government (Landsgemeinde) for the whole canton. All cantons allow at least for one type of

${ }^{4}$ For more detail see Marchand (1999) and Muzellec (1994). 
direct voter control. Namely, even in cantons where citizens cannot vote directly on specific pieces of legislation, partial or total revision of their constitutions are subject to a constitutional referendum. When it comes to allowing for mandatory or optional statutory referenda, and constitutional or statutory initiatives, there is no general rule; these features vary from canton to canton. In addition, specific fiscal and administrative referenda exist. ${ }^{5}$ We focus on fiscal referenda on new spending projects, tax law changes or the issuing of new bonds, but we also consider statutory initiatives.

Figure 1 provides a canton-by-canton geographical summary of the types of fiscal referendum allowed for in 1996. The cantons in white are those that have mandatory and optional fiscal referenda, the cantons shaded light-grey are those with mandatory fiscal referenda only, while dark-grey indicates only optional fiscal referenda. The canton of Vaud (black) does not allow for any type of fiscal referendum. Thus in 1996, 17 cantons had a mandatory fiscal referendum and 20 cantons an optional fiscal referendum. For the purposes of this map, fiscal referenda refer to fiscal referendum on new spending projects, but we note that fiscal referenda may also apply to tax changes and new bonds issues.

What is important to note here is that the spending threshold is larger for the mandatory than for the optional referendum. In the majority of cantons, the spending

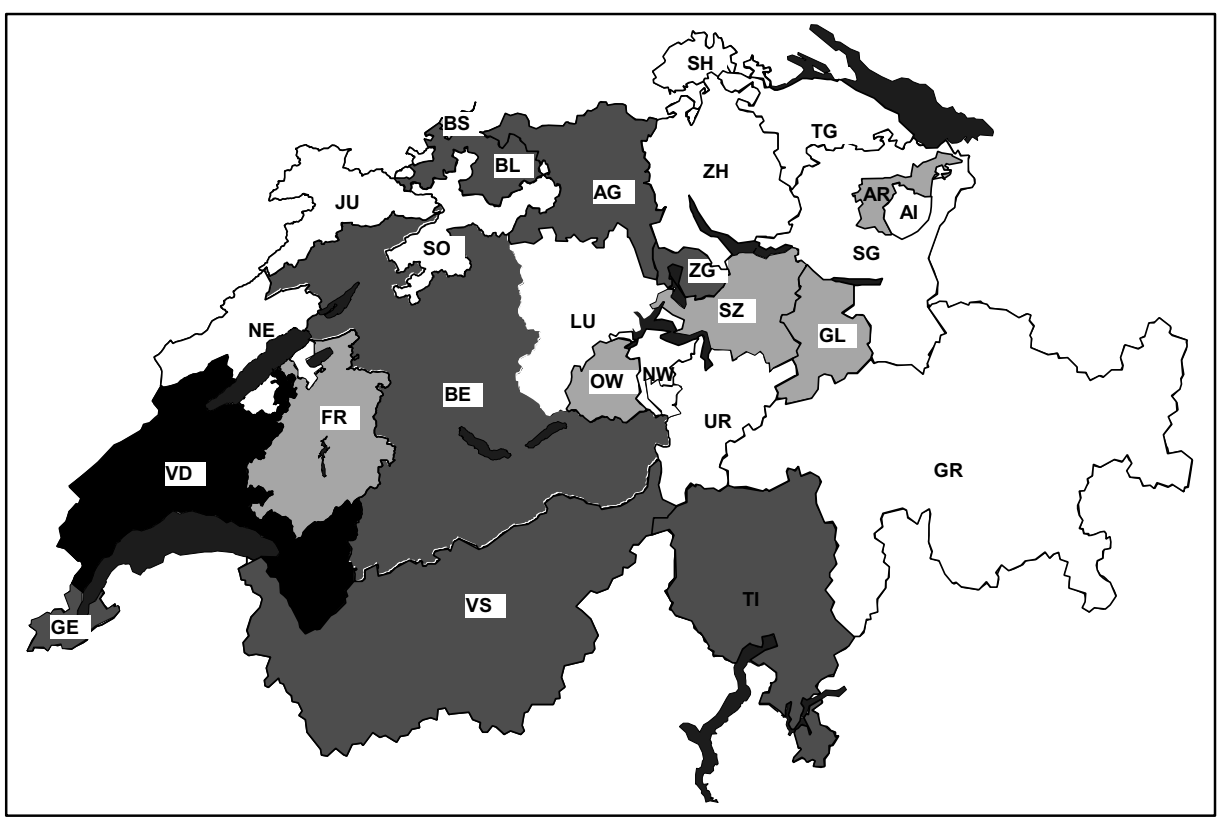

Figure 1. Provisions for budget referenda in Swiss cantons, 1996

Source: Feld and Matsusaka (2000).

${ }^{5}$ Trechsel and Serdült (1999) provide a comprehensive description of the political structures of Swiss cantons. Referenda and initiatives are also widely used at the Swiss local level. 
threshold is denoted in absolute nominal terms. In 1996, it ranged for the mandatory referendum from the Swiss franc equivalent of approximately $\$ 140000$ in canton Schwyz to approximately $\$ 14$ million in canton Luzern. The incentive it provides to representatives is clear. If the project costs less than the threshold amount, a referendum can be circumvented. The referendum's ability to restrict representatives thus depends on their ability to divide projects.

In Switzerland, voter initiatives differ from referenda mainly in terms of agenda-setting power. Via the initiative route, groups of voters can propose a new project or law; this is put to a popular vote if a sufficient number of citizens support the initiative, that is, if a predetermined number of signatures can be collected. The higher the number of signatures, the more difficult and costly it is to run an initiative successfully. In the case of public spending, the initiative allows voters to eliminate spending programmes, even those that fall below the spending threshold for mandatory referendum. Constitutional and statutory initiatives are available in all cantons. Signature requirements range from one in the town-meeting cantons to 15000 in the canton of Bern in 1996. In all cases, the referendum and the initiative are adopted by a simple majority of the people who actually vote, that is, there is no quorum requirement stipulating a minimum participation rate for the result to be valid.

3.3.1. Fiscal restraints. In addition to direct democracy, fiscal issues are influenced by fiscal restraints that are enforced by the courts or by higher levels of government. Such restraints usually are observed in cantons that have provisions for fiscal referenda. While nearly all cantons have constitutional fiscal restraints that require them to balance their budget over time in one way or the other, only five cantons, Fribourg (FR), Solothurn (SO), Appenzell a. Rh. (AR), St Gallen (SG) and Graubünden (GR), have statutory fiscal requirements (Stauffer, 2001: p. 72). These require the cantons concerned to increase tax rates if budget deficits surpass a deficit threshold. In Fribourg, this requirement is specified such that local taxes are not covered, but a bailout of the cantonal by the local level is highly improbable. The cantons of St Gallen and Solothurn have additional restrictions on tax rate cuts that provide additional restrictions on deficit financing. The requirements are less restrictive in Appenzell a.Rh., and much less so in Graubünden.

To be able to evaluate proposals of an introduction of referenda and initiatives in regional or local decision-making, it is useful to understand how these instruments work. Thus, having illustrated the range of local and regional governance structures, we turn now to the theory on how and why direct democracy might affect the outcome of local governance.

\section{THE POLITICAL ECONOMY OF DIRECT LEGISLATION FROM A THEORETICAL PERSPECTIVE}

The constitutional choice between more or less direct forms of democracy entails a trade-off between information costs and loss-of-control by the people. In particular, 
representative democracy is supposed to have an informational advantage compared to direct legislation, so citizens delegate decision-making power to representatives in the public sector in order to save information costs. However, representatives then have leeway to act opportunistically or in the self-interest of narrow groups. We analyse this trade-off first by considering the information transmission in direct and representative democracies. Next we investigate the impact of referenda and initiatives in a game theoretic context assuming symmetric information of all players. Finally, we discuss how the introduction of asymmetric information changes the outcomes of referendum and initiatives by taking into account the impact of interest groups.

\subsection{The trade off between informed decision-making and popular control}

Representative democracy involves a loss of voter control, but this loss is typically viewed as being compensated for by an increase in the degree to which decisions are informed. In this view, people delegate decision-making power to political specialists in order to decide political issues for the same reason that they grant their fund manager the power to trade shares in their portfolio.

More specifically, politics can be thought of as a result of specialization of people having different abilities. According to Besley and Coate (1997) some citizens have comparative advantages in doing politics, and some of these decide to become 'candidates', that is, professional politicians. In elections, the candidate who gets the highest vote share wins and imposes his/her preferred policies after the election. Citizens have incentives to vote for candidates only on the basis of their preferences and policymaking abilities. The resulting discretionary power of policy-makers provides incentives for candidates to endogenously acquire information, that is, to acquire competence on political issues and to specialize in specific fields. In this framework, political decisions in purely representative democracies are viewed as being taken on the basis of more information. The division of labour continues even at the level of parliament, where a small number of specialized and informed legislators in committees predetermine decisions. Since fewer decision-makers are involved in such committees, each decisionmaker obtains a higher chance of being influential and thus has incentives to acquire even more information. Moreover, the supply of information to fewer people is also less costly. Both mechanisms work in the same direction leading committee specialists to be better informed than the ordinary representative. The power of committee specialist results from the fact that parliaments almost always follow the positions formulated by committee specialists. Indeed, in parliaments with a whipping system, ordinary parliamentarians are obliged to follow such positions since deviations from party positions may lead to sanctions that can include the end of a political career.

4.1.1. Control by voters: political competition and referenda. Even in such a system, it is possible that a simple majority of voters could enforce its preferences. The enforcement mechanism is political competition between different parties or candidates. 
For political competition to work, voters have to be well informed about politics in order to evaluate correctly the performance of incumbents or parties during their years in office. However, given the high costs and low personal benefits accompanying the gathering of political information, one cannot expect voters to have sufficient knowledge of political issues; this in turn reduces the ability of political competition to enforce citizens' preferences. Indeed formal theoretical modelling suggests that this informational asymmetry between representatives and citizens entails a loss of control of the former by the latter and more generally leads to deviations of policy outcomes from citizens' preferences (Kessler, 2001).

A famous example of such systematic deviations from citizens' interest is 'pork-barrel politics' where parliamentarians strive to obtain public services for their district while spreading the cost-burden of these over taxpayers from all districts. As Weingast, Shepsle and Johnsen (1981) show, this behaviour leads to a so-called common pool problem; just as public access to the village commons led to overgrazing in mediaeval England, porkbarrel politics results in the fiscal 'commons' being over-exploited. The reason is that when representatives act, they take into account the concentrated benefits for their district, but consider only a fraction of the costs. Since each representative behaves in this manner, the size of government spending and taxation becomes inefficiently high.

From this perspective, where policy outcomes deviate systematically from citizens' preferences, referenda and initiatives serve as a means of selectively controlling representatives between election years. For example, direct democracy can help mitigate the common pool problem. Citizens who decide on the level of public goods in a referendum consider the total social costs of public funds (rather than just a fraction) because voters from the whole polity (rather than only those from one district) decide on spending. Moreover, the citizens from the districts that benefit directly from locally concentrated public services cannot engage in region-wide vote trading with other districts. More generally, citizens can use a binding referendum to reject government statutes or constitutional amendments, thus referenda can control what governments actually do. Popular initiatives, by contrast, allow control of what governments do not do. That is, citizens can use initiatives to propose policies that have been neglected by the political establishment.

In short, while representative democracy may have an information advantage over direct democracy, direct democracy - via referenda and initiatives - allows citizens to control representatives more closely.

\subsection{Referendum and initiative in a direct democracy}

How do referenda and initiatives actually restrict representatives in their political decisions? Both institutions shape a political game in which several actors play a role. If the government is allowed to propose a policy change, it sets the agenda, that is, which questions are to be decided and which alternatives are excluded. As an agenda setter, it may succeed in proposing a policy that is closer to the preferences of the majority of 
citizens than the status quo. Then, the citizens will accept such a proposal even if it does not coincide with the ideal position of the majority. In contrast to referenda, initiatives shift agenda setting power to citizens.

4.2.1. A simple model. To show how different institutional arrangements affect budgetary outcomes, we work with a simple analytic framework that permits us to focus on the essential interactions between policy-makers and citizens. ${ }^{6}$ In particular, assume that public expenditures are only financed by taxes, so any expenditure increase induces higher taxes as well. Although budgetary decisions often involve choices along several dimensions (e.g., a project's size and location), we keep the model as simple as possible by assuming that the range of policy choices is uni-dimensional. Specifically the policy to be decided is the level of spending on a particular project. Further simplification is obtained by assuming that the preferences of political actors take a particular form. That is, each political actor is assumed to have a preferred level of spending (called his/her ideal point); the farther away the actual expenditure level is from this point, the less happy the actor is about the outcome. To start with, we assume that all political actors are fully informed about the preferences of all others actors as well as the structure of the game. Finally, we assume that the government dislike having its decisions revised by others.

Figure 2 illustrates a situation where the level of spending on a new project must be decided. Three points on the line are of particular importance. First, the current spending level, the status quo, is denoted by q; this is the so-called reversion point, that is, the level of spending that will occur if no decision is reached. Second, point $G$ shows the government's preferred spending level. We assume that the government prefers a higher spending level than the median voter due to, for example, pork-barrel politics. Note that $G$ should be interpreted as the government's preference for the new spending project taking into account the possibility of losing an election and other political costs. Third,

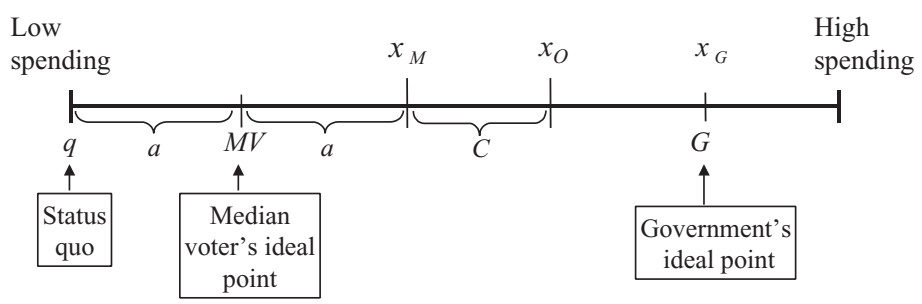

Figure 2. Budgetary policy making with a fiscal referendum

\footnotetext{
${ }^{6}$ This model is adapted from Romer and Rosenthal (1979). Its assumptions are standard in spatial voting models; see Romer and Rosenthal (1979), Steunenberg (1992), and Feld and Matsusaka (2000a). The model representations in Figures 2 and 3 draw on Feld and Matsusaka (2000a: Section III).
} 
the point marked $M V$ represents the ideal point of the 'median voter', that is, we assume that citizens have a range of ideal points and $M V$ marks the level of spending where the ideal points of half the citizens lie to the left and half lie to the right.

The median voter's ideal point can be thought of as representing something like the will of the people. For instance, competition between two political parties on this single issue would result in both parties proposing $M V$. To see this, note that if one party proposes $M V$ and the other proposes something higher than $M V$, say $M V+1$, the former - call it the $M V$-party - would win. The reason is that voters with ideal points lower than $M V$ prefer $M V$ to $M V+1$ and would thus vote for the $M V$-party (recall that by construction, this group includes exactly half the voters); voters with ideal points higher than $M V+1$ would vote for the $M V+1$ party and the two parties would split voters whose ideal points lay between $M V$ and $M V+1$. Given this, we see that the $M V$-party would attract more than half the votes and so would win. The same logic shows that proposing something less than $M V$ would also be a losing strategy, so both parties would propose $M V$, and as a result, $M V$ would be the outcome regardless of which party won. $M V$ would also be the probable outcome in a pure direct democracy, for example in a town meeting of all citizens.

Using this framework, we consider which decision would be taken under four institutional arrangements: representative democracy, mandatory referenda, initiatives and fiscal restraints.

\subsubsection{Outcome with a representative democracy versus mandatory refer-}

endum. If no referendum or initiative is possible, the government is free to choose the spending level, so it would choose its preferred point $G$. Compare this to the outcome that would emerge when a referendum is mandatory. In this case, the government gets to decide the exact size of the project to be voted on, but voters will reject any spending proposal that is not preferred to the status quo. As it turns out, the government will propose a project with the spending level marked as $x_{M}$ in Figure 2. The level $x_{M}$ is constructed so that at this point, citizens are just indifferent between $x_{M}$ and the status quo spending level, $q$ (they are indifferent since both $x_{M}$ and $q$ are equidistant, namely the distance $a$, from $M V)$. Knowing that spending levels higher than $x_{M}$ would be rejected, the government proposes $x_{M}$ since this is the level of spending closest to its own ideal point, $G$. The diagram is drawn such that $G$ is higher than $x_{M}$, however if $G$ were below $x_{M}$, the referendum would have no effect since the government would propose its preferred point and voters would adopt it since they would prefer it to the status quo. Thus, an important point here is that the referendum results in lower government spending when voters' preferences on spending are sufficiently different from the government's preference. Moreover, referenda boost the power of citizens even when very few 'no' votes are observed. In short, the power of referendum lays mainly in the way that it induces the government to propose policies that are close to the wishes of the majority.

Mandatory referenda, however, are not the only possible type. We turn next to the outcome under an optional referendum. 
4.2.3. Outcome with an optional referendum. The optional referendum only takes place if a certain number of citizens sign a petition that calls for the government to hold a referendum. Collecting such signatures is costly and to be concrete we suppose that $C$ is the cost of collecting the necessary signatures. As it turns out, this tends to loosen voters' control over the government. In particular, the government will now be able to propose a spending level that is somewhat further from the median-voter point $M V$. This is because the government must make the voters indifferent between its spending proposal and the status quo minus the costs of collecting signatures (if voters manage to reject the proposal after having paid $C$, they will have utility equal to $q-C)$. The maximum spending proposal at which this is achieved is $x_{0}$; note that this is higher than $x_{M}$ by exactly the amount $C$. As before, the possibility of an optional referendum will only change the outcome if the government's preferences deviate sufficiently from that of the $M V$. For instance, if $G$ is between $x_{0}$ and $M V$, then the government would choose $G$ with or without the possibility of an optional referendum.

To summarize, we note that if the government wants to spend more money on this project than the majority of voters, the system of mandatory or optional referendum tends to force the government to propose a project that is closer to the preferences of the citizens, with mandatory referendum being somewhat stricter than the optional referendum. Moreover, even in cases where the referenda do not constrain the government, the outcome will not be farther away from the preferences of the median voter than it would be in a democracy without referenda. Similar conclusions can be drawn with respect to an under-spending problem.

4.2.4. Outcome with initiatives. Finally, let us consider a polity in which popular initiatives are available. Figure 3 shows the situation. Recall that an initiative allows voters to propose any level of spending and if the proposal is accepted in a popular vote, this spending level is implemented. Thus, if voters can collect the necessary signatures to make a proposal, they can achieve their optimal spending level, namely $M V$. We suppose that collecting signatures for an initiative entails a cost of $K$ that is born by the voters. The trade-off facing voters involves the cost $K$ on one hand and the improved level of spending on the other. Plainly, voters will bear the cost $K$ only if the government's proposal is sufficiently far away from their ideal point. Knowing this, the government

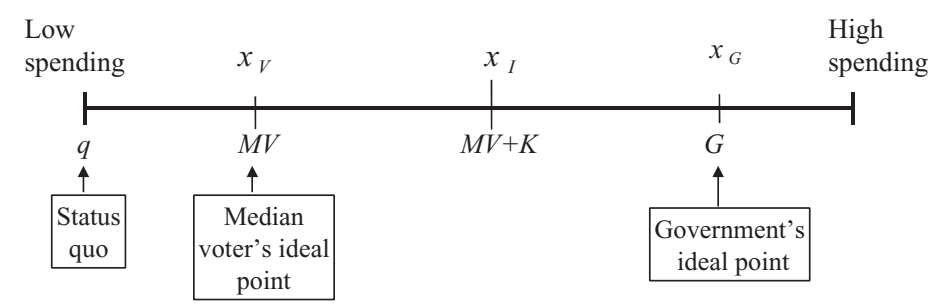

Figure 3. Budgetary policy making with an initiative 
would propose $x_{I}$, which is the highest level of spending that would make voters indifferent to investing $K$ in an initiative. Clearly the signature requirement that leads to cost $K$ is important. The higher is the signature collection cost, the higher is - ceteris paribus - the spending level proposed by the government. If the maximum spending level proposed in an initiative is lower than the spending level preferred by the government, then the initiative will restrict government spending to be closer to the citizens' preferences than $G$.

It is worth noting that there is a relationship between the mandatory fiscal referendum outlined above and the initiative when they both are possible. If the maximum spending level proposed in an initiative, $x_{I}$, is lower than the maximum spending which would still be accepted by the citizens in a mandatory referendum, $x_{M}$, then the initiative is binding and the mandatory referendum has no effect.

4.2.5. Fiscal restraints. Instead of using a referendum or an initiative to restrict policymakers in their spending discretion, voters can impose legal restraints on the government at the constitutional or statutory level. Compared to referenda and initiatives, formal fiscal requirements have the advantage that voters do not have to interfere each time a new spending project is proposed. Rational voters can just forecast the spending requirements of a polity in the future and set the fiscal restraints respectively, thus saving information and transaction costs. The distinction between constitutional and statutory fiscal restraint lies in the difficulty of changing the restrictions. It is easier to change statutory than constitutional fiscal restraints because the latter usually require a larger majority for changes. The disadvantage of formal restraints is to be found in the inflexibility of the instrument. It may thus be more favourable for citizens to control governments' spending behaviour selectively by referenda or initiatives instead of using formal requirements, but it can also be advantageous to employ both instruments.

The reasoning so far suggests that referenda and initiatives can induce a correction of political outcomes in favour of the preferences of the median voter, even in the case of strategic manipulation or agenda setting by the government. This reasoning, however, has abstracted from issues of poorly informed voters or governments. This very natural possibility may alter the outcomes and it is to this possibility that we turn next.

\subsection{Imperfect information and the role of interest groups}

The foundation of the reasoning in Figures 2 and 3 rests on the notion that direct expressions of the 'will of the people' tends to move the outcome towards the ideal point of the median voter. This need not be the case when some actors are less informed than others (see Matsusaka, 1992; Marino and Matsusaka, 2000; Matsusaka and McCarty, 1998; Kessler, 2001 for the formal reasoning on which this section is based).

For example, the fact that political actors are unevenly informed can have an impact on the functioning of the mandatory referendum. To see this, consider a situation similar 
to the one discussed above, in which the government has a bias towards higher spending, but additionally, assume that the government is better informed than citizens. When decisions are made under a system of partial delegation (such that voters can veto or override a spending proposal ex post by a referendum or an initiative), the government has an incentive to supply biased information to citizens in order to obtain their approval for higher spending levels. Moreover, formal modelling shows that these information biases can be severe enough to make full delegation (i.e., representative democracy) a superior system for routine projects. However, if, as seems reasonable, it is more difficult to distort information on large projects than on small ones, the best decision-making system may be two-tiered. That is, one in which there is full delegation for projects below a certain spending threshold, but mandatory referendum for larger projects. Formal reasoning in this literature also suggests that it may make sense to decide distributive issues via direct democracy, but efficiency issues via representative bodies.

Another type of information asymmetry may also alter the attractiveness of direct democracy, namely when the government is imperfectly informed about citizens' preferences. When this is true, special interest groups may be able to strategically manipulate the shape of the government's proposal via the threat of an initiative. Specifically, by pretending that their ideal point is closer to the ideal point of citizens than is the government's, a special interest group may induce the government to propose a project that is more favourable to its interests, even when this actually moves the policy outcome further away from the ideal point of the median voter.

In short, imperfect and asymmetric information may provide opportunities for interest groups to unduly influence political outcomes in direct democracies. However, these groups also influence policies in representative democracies; on the whole and in a comparative perspective, the impact of interest groups is not at all clear. On the one hand, their impact is more visible in direct legislation than in representative democracies because their positions are discussed openly in referendum campaigns. On the other hand, interest groups influence drafted bills in representative democracies by convincing (or bribing) legislators in the early stages of the legislative process. Finally, since referendum campaigns are costly, particularly well-organized and wealthy interest groups have the ability to successfully run referendum campaigns. On this point, we have some empirical evidence. According to the evidence on campaign spending (Longchamp, 1991 for Switzerland and Gerber, 1999 for the US), economic interest groups use direct legislation less often than citizen groups to pass new laws by initiatives, but they use direct legislation more often to preserve the status quo or to pressure the legislature. Economic groups have more success in blocking measures through opposition spending, but are not able to pass new initiatives, whereas citizen groups are more successful in passing new initiatives.

Given this, the question then becomes whether special interests have a stronger influence on policy outcomes in referenda and initiatives than they have in purely parliamentary democracies. Here again we have some evidence for the US and Switzerland. This suggests that political outcomes are closer to citizens' preferences 
under direct democracy than they are under representative democracy. For example, using aggregate data on Swiss cities in 1970, Pommerehne (1978) shows that the median voter model performs better in jurisdictions in which political decisions are taken directly by voters in referenda and initiatives. Gerber (1996a, 1999) presents evidence for the US that strongly support Pommerehne's result. For two political issues, parental consent laws and capital punishment, she shows that initiatives correct policy outcomes towards the preferences of the median voter. Gerber (1996b) also provides evidence that the deviation of policy outcomes from citizens' preferences can be traced back to the influence of interest groups on representatives.

4.3.1. Summary. This theoretical background helps highlight the issues but, as usual, it cannot provide a conclusive assessment as to whether institutions of direct democracy have a positive or negative impact on policy outcomes. The reasoning does, however, suggest that fiscal outcomes should depend upon the precise system of local governance. If this is true, then the choice of local governance is a matter of substantial policy concern. This brings us to the topic of the next section, namely the empirical evidence on the fiscal impact of direct democracy.

\section{AN ECONOMETRIC MODEL OF THE FISCAL IMPACT OF DIRECT DEMOCRACY}

In this section we focus on fiscal policy. Fiscal policy is certainly only one of many important political issues, and for some people it might not be the most important one. However, it is - without doubt - important in itself, and it is also easy to measure, thus making it possible to get reliable empirical evidence about the differences between the political outcomes of (semi-) direct versus purely representative political systems. Moreover, if there are significant differences with respect to fiscal policy, we are quite sure that there exist similar differences with respect to other policy areas as well.

\subsection{Testable hypotheses}

The theory discussed above allows us to derive empirically testable hypotheses. The simplest addresses the question of whether direct democracy institutions have any impact on policy outcomes at all. Are referenda and initiatives simply veils for rational decisions of individuals? Or do they shape (economic) policy outcomes and successfully serve as restrictions on individual behaviour? In this light, the first hypothesis to test is:

Hypothesis 1: (Economic) policy outcomes in pure representative (parliamentary, presidential) democracies do not significantly differ from those in democracies with referenda and initiatives.

From Hypothesis 1, the direction of the impact of referenda and initiatives on public policy is still not clear. Yet if voters are more fiscally conservative than representatives, as 
Peltzman (1992) shows for the US, then the theory in Section 4 suggests that spending should actually be lower in a direct democracy than in a representative democracy. In addition, referenda and initiatives should help to mitigate 'common pool' problems since citizens consider the total social costs of public funds and not only a fraction of it. More generally, referenda and initiatives should move policy outcomes closer towards the preferences of citizens, at least towards that of the median voter. Hypothesis la follows directly:

Hypothesis 1a: Referendum and initiative outcomes entail lower spending (and revenue) levels than budgetary decisions derived only in the parliamentary process.

In order to test the hypotheses empirically, we focus on the fiscal policy issues of Swiss cantons and local jurisdictions.

\subsection{The basic empirical model}

The first task is to introduce the basic econometric model that we shall employ in our analysis of fiscal policy outcomes (note that models of this type are quite common in empirical studies of fiscal policy). ${ }^{7}$ Specifically, the model supposes that three types of variables explain fiscal outcomes:

- institutional variables (e.g., which types of referendum, if any, are allowed);

- economic and socio-demographic controls; and

- political controls.

In order to look at fiscal policy as comprehensively as possible, we apply the model to four measures of fiscal policy: public expenditure, public revenue, budget deficits, and public debt.

The Web Appendix for this article (available at www.economic-policy.org) provides further detail on data sources, the model specification and various econometric issues.

5.2.1. Institutional variables. The first and most important institutional variable is the dummy variable for fiscal referenda. In our implementation, this equals unity if a canton has a mandatory fiscal referendum and zero otherwise. If this variable is significant, we are able to reject Hypothesis 1. Given the results by Peltzman (1992) that voters are fiscally more conservative than representatives, we can expect that fiscal referenda restrict the spending capabilities of representatives in a way that corresponds to Hypothesis 1a. That is, fiscal referenda lower spending, revenue, deficits and public debt. As a second variable, the number of signatures (as a percentage of the population) required to hold a statutory initiative is included in the model in order to measure the restriction the initiative imposes on spending by representatives. We assume that the

${ }^{7}$ For similar models see the Roubini and Sachs (1989) and the de Haan and Sturm (1994) models of deficit and debt, and the Matsusaka (1995) model of spending and revenue. 
higher is this share, the higher is the cost of a referendum for citizens. Given the theoretical reasoning in Section 4, we expect a higher signature requirement to imply a less stringent restriction on public spending. Thus, the signature requirement should have a positive impact on the fiscal variables.

The final institutional variable that is included in the model is an index of statutory fiscal restraints. As we have constructed it, the index ranges from zero in cantons with no statutory fiscal restraint to three in the cantons with the most stringent restraints. According to the theory, more restrictive statutory constraints should, controlling for other factors, yield sounder public finances, that is, lower public spending, budget deficits and public debt. Since these requirements have a strong revenue bias forcing the cantons to avoid deficits by higher tax rates, the sign of this variable on public revenue is not determined a priori; it might lead to higher revenue. But if this is the case, the size of the coefficient in the revenue equation should be smaller than the one in the spending equation.

5.2.2. Economic and socio-demographic control variables. Economic and sociodemographic control variables include income, unemployment rates and the structure and size of the population. The most important of these variables is income. Generally, over time higher income is supposed to lead to higher spending and revenue (and possibly also to higher debt and deficits). Higher spending results because of increased demand of citizens for public services as their incomes increase. Higher revenue results because revenue of the Swiss cantons and local jurisdictions is mainly derived from progressive or proportional income taxes. However, this does not necessarily imply that in the cross-section domain the same relation holds. It might be the case, for example, some services (like schools) tend to be provided privately in 'rich' local communities; this would yield the result that lower per capita public revenue and spending is associated with lower income per capita. To take account of this possibility, we measure income by two variables in the cantonal model. One variable is national GDP per capita which is (necessarily) the same for all cantons and describes the common economic development in Switzerland. The other variable is the difference between cantonal and national GDP, which is supposed to capture canton-specific developments.

In addition, the unemployment rate is included in the model to proxy business cycle developments. Higher unemployment is expected to trigger higher spending, lower revenue, higher budget deficits and higher public debt. In order to control for the impact of intergovernmental grants between jurisdictions, the model also contains federal lump sum grants per capita. Lump-sum grants enable cantons instead to allocate the funds according to their own priorities. A higher level of lump-sum grants should lead to higher spending as well. In addition, to the extent that a high grant level is related to a high level of bail-out by other jurisdictions, grants might lead to lower incentives to use the resources economically. Therefore, it may, ceteris paribus, tend to encourage higher budget deficits and public debt. 
A number of demographic variables are also included. The number of inhabitants can play a crucial role on the level of public expenditure, so cantonal population is included. In addition, population density and the share of the urban population are included in the model. Moreover, since different age groups have different preferences for public spending, we control for the demographic structure of a canton by using the shares of the population older than 65 and younger than 20 years. Both variables may be interpreted as indicating the demand of these two particular population groups for public spending as well as their ability to generate public revenue. We also include a regional variable reflecting the language differences among the Swiss cantonal and local communities. This variable is the share of the French and Italian speaking population. A quite common prejudice is that 'Latin' cantons and communities have higher preferences for 'public sector solutions' of social problems and are thus inclined to have more 'unsound' public finances, that is, higher spending, higher revenue, higher deficits and higher debt.

5.2.3. Political control variables. As a second group of controls, the model contains a number of political variables. The first one follows the arguments of the partisan cycles models that left-wing parties generate unsound public finances. If this notion is correct, the share of left-wing parties in the parliament should have a positive impact on the level of public spending, public revenue, budget deficits and public debt. The second political variable measures the strength of an executive government by introducing the number of coalition parties in the executive. As outlined by Roubini and Sachs (1989), the more political parties are involved in the executive, the larger budget deficits and public debt should be. This impact is derived from the common-pool argument that the more parties are involved in the government the more constituencies must be satisfied with specific public services which leads to higher spending. In addition, the less revenue is generated because the tax burden should not fall on these particular constituencies. This leads to higher debt in the long run. However, because the members of the Swiss cantonal and local governments are in nearly all cases directly elected, there is a broad representation in most Swiss sub-federal governments and this is distinct from 'Roubini-and-Sachs-type' coalitions. Consequently, this variable may not be significant in the Swiss case.

A first inspection of the data shows that there are two cantons (the cantons of BaselCity and of Geneva) that have exceptionally high public revenue and expenditure compared to all other cantons. Both of these are 'city cantons'. ${ }^{8}$ Instead of dropping these 'outliers', we add the dummy variables 'D-Basel-City' and 'D-Geneva' for those cantons (the dummy variable takes a value of one in the case of the respective canton and zero otherwise). There is, however, another outlier in the data, revenue of the canton Appenzell a.Rh. in 1996. In this year, cantonal revenue lies at about 50\% above the 'normal' value, because this canton sold its 'own' cantonal bank to the Union Bank of

\footnotetext{
${ }^{8}$ The distributions of revenue and expenditure are bimodal, with the upper part consisting only of observations from these two cantons. Excluding these observations, the null hypothesis of a normal distribution cannot be rejected (i.e., the Jarque-Bera test yields a $p$-value of 0.160 for cantonal expenditure and of 0.286 for cantonal revenue per capita).
} 
Switzerland (UBS) and this created large additional revenue. In order to take account of this special development, we subtracted the extraordinary revenue from total revenue of that canton in this year. ${ }^{9}$

The difference between cantons with and without direct democracy can be measured directly by a dummy variable. However, it is possible that such differences occur because direct democracy has an indirect impact through other variables, rather than through the impact of referenda and initiatives on government behaviour. To investigate this possibility, we always performed a standard statistical test (Chow test) to see if the model performs in statistically similar ways on the two samples (cantons with and without direct democracy for fiscal issues). ${ }^{10}$ With the exception of the two debt equations, the maintained hypothesis that there is no difference between the samples could always be rejected on statistical grounds. However, especially the equations for the representative democracies have to be interpreted cautiously, since we have only 95 observations and these are from only 9 cantons. This is certainly not sufficient to draw strong conclusions, especially with respect to the variables that display little variation over time. See the Web Appendix, point $\mathrm{B}$ for more detail on statistical issues. The Web Appendix can be found on http://www.economic-policy.org.

\subsection{Results for the Swiss cantons}

The model is estimated on annual data from 1986 to 1997 for 26 cantons. The results for the log of public spending and revenue are given in Table 2, and those for the log of public debt and the absolute value of budget deficits in Table 3. For comparability, the estimates for the whole and the two sub-samples (cantons with and without direct democracy on fiscal issues) are reported together.

Overall, the models for the total period as well as for the two sub-samples explain the variance of cantonal public spending, revenue and deficits quite well. By contrast, very little of the variance of cantonal public debt is explained by the model. As was to be expected from the results of the Chow test, the coefficients in the models for the two sub-samples are quite different, while - owing to the larger number of observations - the coefficients in the common model are mostly quite similar to those in the equations for the direct democracies, that is, those which have a mandatory fiscal referendum. Such differences can be observed for most of the variables, the political, the structural and even for the economic ones. This reinforces the suspicion that there is a structural break between these two sub-samples and further justifies the estimation of separate equations. ${ }^{11}$

\footnotetext{
${ }^{9}$ The estimation results are generally robust to the inclusion of dummy variables. See, for example, the results in Feld and Matsusaka (2000a) for a similar model.

${ }^{10}$ Thus, we estimate the equations not only over the pooled sample by including a dummy variable for mandatory fiscal referenda to take account of the difference, but also for the two sub-samples.

${ }^{11}$ Moreover, the results for the Jarque-Bera test for the expenditure and revenue equations reject the null hypothesis of normality of the residuals on the 5 and $10 \%$ significance levels, respectively, while this hypothesis cannot be rejected for the sub-samples.
} 
Table 2. Net cantonal public expenditure and revenue, 1986-97

\begin{tabular}{|c|c|c|c|c|c|c|}
\hline & \multicolumn{3}{|c|}{ Expenditure equations } & \multicolumn{3}{|c|}{ Revenue equations } \\
\hline & $\begin{array}{c}\text { All } \\
\text { cantons }\end{array}$ & $\begin{array}{c}\text { Cantons } \\
\text { with direct } \\
\text { democracy }\end{array}$ & $\begin{array}{l}\text { Cantons } \\
\text { with rep. } \\
\text { democracy }\end{array}$ & $\begin{array}{c}\text { All } \\
\text { cantons }\end{array}$ & $\begin{array}{c}\text { Cantons } \\
\text { with direct } \\
\text { democracy }\end{array}$ & $\begin{array}{l}\text { Cantons } \\
\text { with rep. } \\
\text { democracy }\end{array}$ \\
\hline $\begin{array}{l}\text { Fiscal referenda } \\
\text { dummy }\end{array}$ & $\begin{array}{c}-0.065 * \\
(2.14)\end{array}$ & - & - & $\begin{array}{c}-0.113 * * \\
(3.87)\end{array}$ & - & - \\
\hline $\begin{array}{l}\text { Signature } \\
\text { requirement } \\
\text { for initiative }\end{array}$ & $\begin{array}{c}-0.086 * * \\
(4.51)\end{array}$ & $\begin{array}{c}-0.095 * * \\
(4.26)\end{array}$ & $\begin{array}{l}0.108 * * \\
(4.81)\end{array}$ & $\begin{array}{c}-0.091 * * \\
(5.86)\end{array}$ & $\begin{array}{l}-0.075 * * \\
(3.74)\end{array}$ & $\begin{array}{l}0.061 * * \\
(3.88)\end{array}$ \\
\hline Fiscal constraints & $\begin{array}{l}-0.003 \\
(0.23)\end{array}$ & $\begin{array}{l}-0.816 \\
(0.94)\end{array}$ & - & $\begin{array}{c}0.017 \\
(1.24)\end{array}$ & $\begin{array}{l}0.013 \\
(1.48)\end{array}$ & - \\
\hline National GDP & $\begin{array}{l}1.113 * * \\
(4.63)\end{array}$ & $\begin{array}{l}1.210 * * \\
(5.58)\end{array}$ & $\begin{array}{l}0.912 * * \\
(4.31)\end{array}$ & $\begin{array}{l}0.465\left(^{*}\right) \\
(1.74)\end{array}$ & $\begin{array}{l}0.815 * * \\
(3.33)\end{array}$ & $\begin{array}{c}0.093 \\
(0.55)\end{array}$ \\
\hline $\begin{array}{l}\text { Difference in } \\
\text { cantonal and } \\
\text { national } \\
\text { GDPs }\end{array}$ & $\begin{array}{l}0.500 * * \\
(5.00)\end{array}$ & $\begin{array}{l}0.875 * * \\
(10.45)\end{array}$ & $\begin{array}{l}-0.212\left(^{*}\right) \\
(1.82)\end{array}$ & $\begin{array}{l}0.450 * * \\
(4.48)\end{array}$ & $\begin{array}{l}0.974^{* *} \\
(12.76)\end{array}$ & $\begin{array}{l}-0.154 \\
(1.46)\end{array}$ \\
\hline $\begin{array}{l}\text { Unemployment } \\
\text { rate }\end{array}$ & $\begin{array}{l}0.014^{* *} \\
(2.92)\end{array}$ & $\begin{array}{l}0.017^{* * *} \\
(4.33)\end{array}$ & $\begin{array}{l}-0.003 \\
(0.71)\end{array}$ & $\begin{array}{c}0.006 \\
(1.15)\end{array}$ & $\begin{array}{l}0.013^{*} \\
(2.85)\end{array}$ & $\begin{array}{l}-0.014 * * \\
(3.64)\end{array}$ \\
\hline Population & $\begin{array}{l}-0.013 \\
(0.99)\end{array}$ & $\begin{array}{l}-0.004 \\
(0.36)\end{array}$ & $\begin{array}{c}0.066 \\
(1.16)\end{array}$ & $\begin{array}{l}-0.023 * \\
(2.06)\end{array}$ & $\begin{array}{l}-0.021 * \\
(2.24)\end{array}$ & $\begin{array}{c}0.052 \\
(1.11)\end{array}$ \\
\hline $\begin{array}{l}\text { Population } \\
\text { density }\end{array}$ & $\begin{array}{l}-0.004 \\
(1.49)\end{array}$ & $\begin{array}{l}-0.002 \\
(0.49)\end{array}$ & $\begin{array}{l}0.027^{* *} \\
(2.73)\end{array}$ & $\begin{array}{l}-0.007 * \\
(2.40)\end{array}$ & $\begin{array}{l}-0.003 \\
(0.95)\end{array}$ & $\begin{array}{l}0.025 * * \\
(3.85)\end{array}$ \\
\hline $\begin{array}{l}\text { Share of old } \\
\text { population }\end{array}$ & $\begin{array}{l}0.016(*) \\
(1.78)\end{array}$ & $\begin{array}{c}0.004 \\
(0.50)\end{array}$ & $\begin{array}{c}0.002 \\
(0.13)\end{array}$ & $\begin{array}{l}0.021 * \\
(2.22)\end{array}$ & $\begin{array}{l}0.009 \\
(1.18)\end{array}$ & $\begin{array}{l}0.026(*) \\
(1.71)\end{array}$ \\
\hline $\begin{array}{c}\text { Share of young } \\
\text { population }\end{array}$ & $\begin{array}{c}-0.019\left(^{*}\right) \\
(1.84)\end{array}$ & $\begin{array}{l}-0.004 \\
(0.52)\end{array}$ & $\begin{array}{l}0.003 \\
(0.18)\end{array}$ & $\begin{array}{l}-0.014 \\
(1.26)\end{array}$ & $\begin{array}{l}0.015(*) \\
(1.66)\end{array}$ & $\begin{array}{l}0.015 \\
(1.29)\end{array}$ \\
\hline $\begin{array}{c}\text { Share of urban } \\
\text { population }\end{array}$ & $\begin{array}{c}-0.003 * * \\
(2.75)\end{array}$ & $\begin{array}{c}-0.004 * * \\
(5.69)\end{array}$ & $\begin{array}{l}0.005 * \\
(2.15)\end{array}$ & $\begin{array}{l}-0.001 \\
(1.11)\end{array}$ & $\begin{array}{c}-0.003 * * \\
(3.35)\end{array}$ & $\begin{array}{l}0.006 * * \\
(3.20)\end{array}$ \\
\hline $\begin{array}{l}\text { Lump-sum } \\
\text { grants }\end{array}$ & $\begin{array}{l}0.094 \text { * } \\
(2.21)\end{array}$ & $\begin{array}{l}0.122 * * \\
(3.40)\end{array}$ & $\begin{array}{l}0.083 * \\
(2.58)\end{array}$ & $\begin{array}{l}0.133^{* *} \\
(3.24)\end{array}$ & $\begin{array}{l}0.232 * * \\
(5.48)\end{array}$ & $\begin{array}{l}0.072 * * \\
(2.79)\end{array}$ \\
\hline $\begin{array}{l}\text { Share of leftist } \\
\text { parties in the } \\
\text { parliament }\end{array}$ & $\begin{array}{l}0.006^{* *} \\
(3.74)\end{array}$ & $\begin{array}{l}0.010 * * \\
(7.18)\end{array}$ & $\begin{array}{l}0.016 * * \\
(7.99)\end{array}$ & $\begin{array}{l}0.005 * * \\
(3.38)\end{array}$ & $\begin{array}{l}0.011 * * \\
(8.13)\end{array}$ & $\begin{array}{l}0.011 * * \\
(5.79)\end{array}$ \\
\hline $\begin{array}{l}\text { Number of } \\
\text { parties in the } \\
\text { executive }\end{array}$ & $\begin{array}{l}0.010 \\
(0.71)\end{array}$ & $\begin{array}{c}-0.282\left({ }^{*}\right) \\
(1.81)\end{array}$ & $\begin{array}{l}-0.009 \\
(0.57)\end{array}$ & $\begin{array}{c}0.022 \\
(1.38)\end{array}$ & $\begin{array}{l}-0.021 \\
(1.17)\end{array}$ & $\begin{array}{l}-0.001 \\
(0.03)\end{array}$ \\
\hline $\begin{array}{l}\text { French language } \\
\text { dummy }\end{array}$ & $\begin{array}{l}0.159 * * \\
(3.62)\end{array}$ & $\begin{array}{l}0.130 * \\
(2.50)\end{array}$ & $\begin{array}{l}0.185^{* * *} \\
(2.90)\end{array}$ & $\begin{array}{l}0.120 * * \\
(2.73)\end{array}$ & $\begin{array}{l}-0.004 \\
(0.08)\end{array}$ & $\begin{array}{l}0.183^{* *} \\
(4.24)\end{array}$ \\
\hline $\begin{array}{l}\text { Dummy for } \\
\text { Basel-Stadt }\end{array}$ & $\begin{array}{l}0.704 * * \\
(5.06)\end{array}$ & - & $\begin{array}{l}-0.233 \\
(0.63)\end{array}$ & $\begin{array}{l}0.813 * * \\
(5.43)\end{array}$ & - & $\begin{array}{l}-0.305 \\
(1.20)\end{array}$ \\
\hline $\begin{array}{l}\text { Dummy for } \\
\text { Geneva }\end{array}$ & $\begin{array}{l}0.790 * * \\
(13.42)\end{array}$ & - & $\begin{array}{c}0.121 \\
(0.64)\end{array}$ & $\begin{array}{l}0.788 * * \\
(12.18)\end{array}$ & - & $\begin{array}{c}0.104 \\
(0.84)\end{array}$ \\
\hline Constant & -3.772 & $-4.918\left(^{*}\right)$ & $-4.350\left(^{*}\right)$ & 3.079 & -1.753 & $4.375 *$ \\
\hline $\bar{R}^{2}$ & 0.917 & 0.774 & 0.983 & 0.902 & 0.702 & 0.985 \\
\hline SER & 0.097 & 0.085 & 0.057 & 0.100 & 0.089 & 0.051 \\
\hline Jarque-Bera & $7.034 *$ & 1.374 & 0.650 & $4.708(*)$ & 4.087 & 0.139 \\
\hline Chow test $(\hat{F})$ & $16.000 * *$ & - & - & $18.333^{* *}$ & - & - \\
\hline Observations & 312 & 217 & 95 & 312 & 217 & 95 \\
\hline
\end{tabular}

Notes: Numbers in parentheses are absolute values of the t-statistics based on heteroscedasticity and autocorrelation corrected standard errors. $* *, *$ or $(*)$ show that the estimated parameter is significantly different from zero on the 1, 5, or $10 \%$ level, respectively. SER is the standard error of the regression. Variables are in logs. Estimation was performed with LIMDEP, Version 7.0. 
Table 3. Gantonal public debt and deficits (in absolute values)

\begin{tabular}{|c|c|c|c|c|c|c|}
\hline & \multicolumn{3}{|c|}{ Debt equations } & \multicolumn{3}{|c|}{ Deficit equations } \\
\hline & $\begin{array}{c}\text { All } \\
\text { cantons }\end{array}$ & $\begin{array}{c}\text { Cantons } \\
\text { with direct } \\
\text { democracy }\end{array}$ & $\begin{array}{c}\text { Cantons } \\
\text { with rep. } \\
\text { democracy }\end{array}$ & $\begin{array}{c}\text { All } \\
\text { cantons }\end{array}$ & $\begin{array}{c}\text { Cantons } \\
\text { with direct } \\
\text { democracy }\end{array}$ & $\begin{array}{l}\text { Cantons } \\
\text { with rep. } \\
\text { democracy }\end{array}$ \\
\hline $\begin{array}{l}\text { Fiscal referenda } \\
\text { dummy }\end{array}$ & $\begin{array}{c}0.059 \\
(0.61)\end{array}$ & - & - & $\begin{array}{c}204.101 * * \\
(2.95)^{* *}\end{array}$ & - & - \\
\hline $\begin{array}{l}\text { Signature } \\
\text { requirement } \\
\text { for initiative }\end{array}$ & $\begin{array}{l}0.007 \\
(0.11)\end{array}$ & $\begin{array}{l}0.118 \\
(1.48)\end{array}$ & $\begin{array}{c}-0.042 \\
(0.28)\end{array}$ & $\begin{array}{c}20.329 \\
(0.48)\end{array}$ & $\begin{array}{c}-63.393\left({ }^{*}\right) \\
(1.66)\end{array}$ & $\begin{array}{l}217.143\left(^{*}\right) \\
\quad(1.88)\end{array}$ \\
\hline Fiscal constraints & $\begin{array}{l}-0.848 * \\
(2.15)\end{array}$ & $\begin{array}{c}-0.070\left(^{*}\right) \\
(1.83)\end{array}$ & - & $\begin{array}{c}-92.945 * * \\
(3.54)\end{array}$ & $\begin{array}{c}-91.859 * * \\
(5.02)\end{array}$ & - \\
\hline National GDP & $\begin{array}{l}2.191^{*} \\
(2.33)\end{array}$ & $\begin{array}{c}0.928 \\
(0.86)\end{array}$ & $\begin{array}{l}2.609 \\
(1.56)\end{array}$ & $\begin{array}{l}0.064 * * \\
(4.88)\end{array}$ & $\begin{array}{l}0.017^{*} \\
(2.03)\end{array}$ & $\begin{array}{l}0.112^{* *} \\
(4.96)\end{array}$ \\
\hline $\begin{array}{l}\text { Difference in } \\
\text { cantonal and } \\
\text { national } \\
\text { GDPs }\end{array}$ & $\begin{array}{l}1.015^{* *} \\
(3.18)\end{array}$ & $\begin{array}{l}1.460 * * \\
(2.93)\end{array}$ & $\begin{array}{l}-0.283 \\
(0.33)\end{array}$ & $\begin{array}{l}0.015^{*} \\
(2.39)\end{array}$ & $\begin{array}{l}-0.009 \\
(1.41)\end{array}$ & $\begin{array}{c}0.009 \\
(0.60)\end{array}$ \\
\hline $\begin{array}{l}\text { Unemployment } \\
\text { rate }\end{array}$ & $\begin{array}{l}0.055 * * \\
(2.84)\end{array}$ & $\begin{array}{l}0.085^{* *} \\
(3.62)\end{array}$ & $\begin{array}{c}-0.026 \\
(0.73)\end{array}$ & $\begin{array}{l}70.920 * * \\
(5.30)\end{array}$ & $\begin{array}{l}32.335^{*} \\
(2.46)\end{array}$ & $\begin{array}{c}104.936 * * \\
(3.32)\end{array}$ \\
\hline Population & $\begin{array}{c}0.045 \\
(0.97)\end{array}$ & $\begin{array}{l}0.008 \\
(0.15)\end{array}$ & $\begin{array}{l}0.164 \\
(0.35)\end{array}$ & $\begin{array}{l}0.206^{*} \\
(2.04)\end{array}$ & $\begin{array}{l}0.265^{* *} \\
(2.84)\end{array}$ & $\begin{array}{l}0.597 \\
(0.73)\end{array}$ \\
\hline $\begin{array}{c}\text { Population } \\
\text { density }\end{array}$ & $\begin{array}{l}-0.012 \\
(1.14)\end{array}$ & $\begin{array}{l}-0.003 \\
(0.29)\end{array}$ & $\begin{array}{l}0.069 \\
(1.15)\end{array}$ & $\begin{array}{l}11.121 \\
(1.27)\end{array}$ & $\begin{array}{l}7.117 \\
(1.04)\end{array}$ & $\begin{array}{c}-3.911 \\
(0.07)\end{array}$ \\
\hline $\begin{array}{l}\text { Share of old } \\
\text { population }\end{array}$ & $\begin{array}{l}0.045\left(^{*}\right) \\
(1.77)\end{array}$ & $\begin{array}{l}0.057\left(^{*}\right) \\
(1.84)\end{array}$ & $\begin{array}{c}-0.076 \\
(0.76)\end{array}$ & $\begin{array}{l}-13.672 \\
(0.62)\end{array}$ & $\begin{array}{c}-30.942 \\
(1.60)\end{array}$ & $\begin{array}{c}-111.352 \\
(1.24)\end{array}$ \\
\hline $\begin{array}{c}\text { Share of young } \\
\text { population }\end{array}$ & $\begin{array}{l}0.103^{* *} \\
(3.08)\end{array}$ & $\begin{array}{l}0.122 * * \\
(3.14)\end{array}$ & $\begin{array}{l}-0.041 \\
(0.42)\end{array}$ & $\begin{array}{c}-13.601 \\
(0.51)\end{array}$ & $\begin{array}{c}-96.236 * * \\
(4.60)\end{array}$ & $\begin{array}{c}56.205 \\
(0.85)\end{array}$ \\
\hline $\begin{array}{l}\text { Share of urban } \\
\text { population }\end{array}$ & $\begin{array}{c}0.002 \\
(0.38)\end{array}$ & $\begin{array}{l}0.001 \\
(0.21)\end{array}$ & $\begin{array}{l}-0.017 \\
(0.96)\end{array}$ & $\begin{array}{l}-6.179 * \\
(2.37)\end{array}$ & $\begin{array}{c}-8.362 * * \\
(2.86)\end{array}$ & $\begin{array}{l}9.490 \\
(1.03)\end{array}$ \\
\hline $\begin{array}{l}\text { Lump-sum } \\
\text { grants }\end{array}$ & $\begin{array}{l}-0.297(*) \\
(1.93)\end{array}$ & $\begin{array}{l}-0.232 \\
(1.20)\end{array}$ & $\begin{array}{l}0.050 \\
(0.15)\end{array}$ & $\begin{array}{l}-0.549 * * \\
(2.66)\end{array}$ & $\begin{array}{c}-1.241 * * \\
(4.63)\end{array}$ & $\begin{array}{c}-0.492 \\
(1.27)\end{array}$ \\
\hline $\begin{array}{l}\text { Share of leftist } \\
\text { parties in the } \\
\text { parliament }\end{array}$ & $\begin{array}{c}0.003 \\
(0.65)\end{array}$ & $\begin{array}{l}-0.002 \\
(0.37)\end{array}$ & $\begin{array}{l}0.007 \\
(0.37)\end{array}$ & $\begin{array}{c}6.343 \\
(1.22)\end{array}$ & $\begin{array}{l}-5.220 \\
(1.18)\end{array}$ & $\begin{array}{l}28.146\left({ }^{*}\right) \\
(1.83)\end{array}$ \\
\hline $\begin{array}{l}\text { Number of } \\
\text { parties in the } \\
\text { executive }\end{array}$ & $\begin{array}{l}-0.062 \\
(1.00)\end{array}$ & $\begin{array}{c}0.072 \\
(0.80)\end{array}$ & $\begin{array}{l}-0.132 \\
(1.26)\end{array}$ & $\begin{array}{l}-61.501 \\
(1.45)\end{array}$ & $\begin{array}{c}-38.901 \\
(0.76)\end{array}$ & $\begin{array}{c}-90.900 \\
(0.81)\end{array}$ \\
\hline $\begin{array}{l}\text { French language } \\
\text { dummy }\end{array}$ & $\begin{array}{l}0.166 \\
(0.85)\end{array}$ & $\begin{array}{l}-0.033 \\
(0.15)\end{array}$ & $\begin{array}{l}0.965 * \\
(2.03)\end{array}$ & $\begin{array}{l}188.021\left(^{*}\right) \\
(1.71)\end{array}$ & $\begin{array}{c}602.790 * * \\
(5.31)\end{array}$ & $\begin{array}{c}91.015 \\
(0.21)\end{array}$ \\
\hline $\begin{array}{l}\text { Dummy for } \\
\text { Basel-Stadt }\end{array}$ & $\begin{array}{l}0.179 \\
(0.39)\end{array}$ & - & $\begin{array}{l}-1.844 \\
(0.84)\end{array}$ & $\begin{array}{c}-365.262 \\
(0.71)\end{array}$ & - & $\begin{array}{c}1156.761 \\
(0.80)\end{array}$ \\
\hline $\begin{array}{l}\text { Dummy for } \\
\text { Geneva }\end{array}$ & $\begin{array}{c}0.979 \\
(0.43)\end{array}$ & - & $\begin{array}{l}-1.205 \\
(0.94)\end{array}$ & $\begin{array}{c}735.673 * * \\
(2.95)\end{array}$ & - & $\begin{array}{c}660.237 \\
(0.63)\end{array}$ \\
\hline Constant & -17.288 & -3.896 & -20.275 & $-4267.251 *$ & $2626.455\left(^{*}\right)$ & $-9040.106 *$ \\
\hline $\bar{R}^{2}$ & 0.046 & 0.073 & 0.026 & 0.516 & 0.475 & 0.668 \\
\hline SER & 0.502 & 0.496 & 0.508 & 338.909 & 251.074 & 406.234 \\
\hline Jarque-Bera & $90.446^{* *}$ & $43.083 * *$ & 39.490 & $40.314 * *$ & $5.575\left(^{*}\right)$ & 6.951 * \\
\hline Chow test $(\hat{F})$ & $1.644\left(^{*}\right)$ & - & - & $5.911 * *$ & - & - \\
\hline Observations & 312 & 217 & 95 & 312 & 217 & 95 \\
\hline
\end{tabular}

Notes: See notes for Table 2. 
5.3.1. Results for democratic institutional variables. The fiscal referendum dummy variable has the expected negative sign and its coefficient is statistically significantly in the expenditure and revenue equations (Table 2, columns 1 and 3). The estimated coefficients indicate that cantonal expenditure and revenue are lower in cantons with fiscal referenda by about $7 \%$ and $11 \%$ respectively. This implies that the budget deficit is larger by about $\$ 115$ per person in cantons without fiscal referenda. In principle this should also be reflected in, ceteris paribus, higher public debt in the Table 3 results, but as it turns out the respective coefficient is not statistically different from zero.

The second main institutional variable, the signature requirement, presents mixed results. On the one hand, the initiative variable has a 'wrong' sign (a higher signature requirement seems to reduce public expenditure and revenue) that is statistically significant when the model is estimated on the whole sample as well as the sample for cantons with direct democracies. On the other hand, the coefficient for the representative-democracy cantons has the expected positive sign and is significantly different from zero in the equations. Taking these results together suggests an interesting interplay between mandatory referenda and initiatives. In cantons with a mandatory fiscal referenda on new spending projects, citizens appear to use the initiative to increase spending, while in cantons without mandatory fiscal referendum, they use initiatives to reduce spending and revenue.

According to these results on referenda and initiatives, Hypothesis 1 has to be rejected: Fiscal policy outcomes are different in cantons with referenda and initiatives. Hypothesis la, by contrast, is supported. Instruments of direct democracy reduce the level of public spending and revenue. They appear to restrict possibilities for pork-barrel politics.

As all the five cantons that have statutory fiscal constraints also have mandatory fiscal referenda, the effect of these constraints can only be distinguished for the cantons with direct democracy. The estimated coefficients show that the constraints reduce public spending and increases public revenue. Though these effects are not statistically significant when it comes to revenue and expenditure (Table 2), the combined negative effect of these fiscal discipline-enhancing devices on public debt and deficits is significant, as the Table 3 results show. According to these estimates, Fribourg, which is the canton with the strongest restrictions, has - ceteris paribus - a per capita deficit that is about $\$ 157$ lower than that of cantons without such restrictions.

\subsubsection{Results on the political and economic controls. The share of leftist parties in} the cantonal parliament has the expected positive sign on expenditure and revenue for both sub-samples, but no effect on public debt. Thus, the hypothesis that left-wing politicians rely more on state solutions of social problems than right-wing politicians is reflected in these results, but there is no indication that they are relying more on public debt than on tax financing of government tasks. Finally, the number of parties in the cantonal executive never has a significant impact in any equation.

Neither the population itself nor any of the variables describing its structure has a consistent impact over the different equations. Moreover, the estimated coefficients are, 
in most cases, insignificantly different from zero, and in several cases they have different signs in the two sub-samples. The share of the old population has a significant positive impact on revenue in the representative democracies, while the share of the young population has a significant (positive) impact only on cantonal debt of the direct democracies. Population density has a significant positive impact on expenditure and revenue in the representative democracies and a significant negative impact on revenue in the whole sample, while the share of the urban population has a significant negative impact in the direct democracies. The share of the French- and Italian-speaking population has a positive impact on both revenue and expenditure in both sub-samples, but the effect is stronger for expenditure and in the representative democracies, such that deficits are higher as well. Consequently, we also find a significantly positive impact on public debt in those cantons.

Real GDP per capita has a proportional impact on expenditure and revenue in the direct democracies; all estimated coefficient are highly significantly different from zero, but they are never significantly different from 1.0. Moreover, cantonal debt also seems to develop proportionally to real income in those cantons. The picture is quite different, however, for the cantons with representative systems. There, the development of the national GDP also seems to have a proportional impact on public expenditure, but no impact at all on public revenue, while the difference of the logarithms of cantonal and national GDP per capita has a negative impact on both public expenditure and revenue in those cantons. National GDP has a stronger and significantly positive impact on budget deficits in representative than in direct democracies. The unemployment rate has a positive impact on spending and revenue in the direct democracies but a negative impact on revenue in the representative democracies. It is also associated with higher deficits and debt. Finally, lump-sum grants have a positive impact on expenditure and revenue in both sub-samples, with elasticities between about 10 and 20\%, and a positive impact on deficits in direct democratic cantons.

Thus, though we have only few variables with consistent effects in both sub-samples, there is evidence that fiscal referenda have a dampening impact on cantonal revenue and expenditure and statutory requirements on cantonal budget deficits. In some cases the effects are statistically not significant, but this might be a result of the small number of cross-sections (cantons), which, due to the relative time invariance of most political and institutional variables, cannot fully be compensated by the fact that we have data for a relatively long period. There is nothing to do about this, however, since we are already using data for all the cantons. To boost the number of data points from different governments, we have to consider lower level jurisdictions. This is what we turn to next.

\subsection{Results for Swiss local jurisdictions}

To check our results from the cantonal data, we re-estimate the model on data from Swiss local communities (most of these have substantial autonomy on fiscal matters). Moreover, differences between the estimates of both levels might indicate to what extent 
direct democracy can be implemented at higher government levels without changing its nature. In principle, we use the same variables to explain local fiscal policy as we used to explain the cantonal data. However, some of the variables we included in the model for the cantons are not available for the local communities and/or do not make sense (e.g., population density, and the share of the urban population). Thus instead of GDP per capita, we use taxable income per taxpayer since it is what we have available. Because we perform a cross-section analysis with only one observation period (the year 1990) it also does not make sense to include national besides local income in the equations. On the other hand, we collected information (from the local constitutions) that allows us to construct a variable 'Agenda' that indicates whether the mayor and/or the head of the finance department of the local government has a strong position in the budgetary process. As constructed, it ranges from 1 to 4 , with 4 indicating the strongest agendasetting power. And finally, we include a dummy variable for the canton Zug (D-Zug) - a canton that has a reputation as a tax haven. Such a status might also have implications for expenditure and revenue of other communities, so we include this dummy in all estimated equations.

We estimated a model in logarithms for expenditure, revenue and debt but also a model in absolute values for the deficit. Contrary to the cantonal estimates, the results of the Chow tests did not indicate that there is a structural break between those local communities with and without fiscal referenda. Thus, we only consider the estimations for the whole sample. The results are given in Table 4. The overall performance as measured by the goodness-of-fit statistic, $\bar{R}^{2}$, is below the values for the cantonal estimates, as might be expected for a pure cross-section analysis. Indeed, the share of the explained variance seems to be quite satisfactory at least for the expenditure and revenue equations. $^{12}$

5.4.1. Results for democratic institutional variables. The dummy variable for referenda on issuing new bonds always has the expected sign and is - except in the deficit equation - significantly different from zero. The estimated value of the coefficient implies that expenditure and revenue in local communities with such referenda are about $20 \%$ lower than in the other communities, while public debt is about $30 \%$ lower. These results corroborate our main finding from the cantonal estimates, that is, that instruments of direct democracy entail lower spending and revenue, at the local level; they even seem to lower public debt.

While the agenda-setting power of the mayor or of the head of the financial department in the local government does not seem to have any effect at all, fiscal constraints have at least a significant impact on the deficit. Depending on the strength of this constraint, it reduces the deficit up to something like $\$ 140$ per person. At first glance, this does not seem to be very much, but comparing this with the average deficit of $\$ 56$,

\footnotetext{
${ }^{12}$ Moreover, the results of the Jarque-Bera test indicate that the null hypothesis of normality of the residuals cannot be rejected on any conventional significance level.
} 
Table 4. Local expenditure, revenue, debt and deficits per capita, 1990

\begin{tabular}{|c|c|c|c|c|}
\hline & $\begin{array}{l}\text { Local public } \\
\text { expenditure }\end{array}$ & $\begin{array}{l}\text { Local public } \\
\text { revenue }\end{array}$ & $\begin{array}{l}\text { Local public } \\
\text { debt }\end{array}$ & $\begin{array}{l}\text { Local public } \\
\text { deficit }\end{array}$ \\
\hline $\begin{array}{l}\text { Dummy of referenda on } \\
\text { budget deficits }\end{array}$ & $\begin{array}{l}-0.209 * * \\
(4.19)\end{array}$ & $\begin{array}{l}-0.210 * * \\
(4.65)\end{array}$ & $\begin{array}{l}-0.313^{* *} \\
(3.24)\end{array}$ & $\begin{array}{l}-18.342 \\
(-0.22)\end{array}$ \\
\hline Fiscal constraints & $\begin{array}{c}-0.013 \\
(0.52)\end{array}$ & $\begin{array}{l}0.007 \\
(0.35)\end{array}$ & $\begin{array}{c}-0.009 \\
(0.20)\end{array}$ & $\begin{array}{c}-60.744^{*} \\
(2.04)\end{array}$ \\
\hline Agenda-setting power & $\begin{array}{l}0.012 \\
(0.51)\end{array}$ & $\begin{array}{l}0.015 \\
(0.72)\end{array}$ & $\begin{array}{c}-0.003 \\
(0.06)\end{array}$ & $\begin{array}{l}-7.844 \\
(-0.21)\end{array}$ \\
\hline Average taxable income & $\begin{array}{c}0.201 \\
(1.09)\end{array}$ & $\begin{array}{c}0.228 \\
(1.14)\end{array}$ & $\begin{array}{c}-0.392 \\
(0.97)\end{array}$ & $\begin{array}{c}0.017 \\
(0.85)\end{array}$ \\
\hline Unemployment rate & $\begin{array}{c}-0.086 \\
(0.85)\end{array}$ & $\begin{array}{c}-0.080 \\
(0.93)\end{array}$ & $\begin{array}{c}0.080 \\
(0.53)\end{array}$ & $\begin{array}{c}37.258 \\
(0.34)\end{array}$ \\
\hline Population in thousands & $\begin{array}{c}0.232 \\
(1.20)\end{array}$ & $\begin{array}{l}0.253 \\
(1.23)\end{array}$ & $\begin{array}{c}-0.288 \\
(0.69)\end{array}$ & $\begin{array}{l}1.499 * * \\
(2.72)\end{array}$ \\
\hline $\begin{array}{l}\text { Share of young } \\
\text { population }\end{array}$ & $\begin{array}{l}-0.044^{* *} \\
(3.68)\end{array}$ & $\begin{array}{l}-0.044^{* *} \\
(3.77)\end{array}$ & $\begin{array}{c}-0.008 \\
(0.36)\end{array}$ & $\begin{array}{c}-5.420 \\
(0.33)\end{array}$ \\
\hline Share of old population & $\begin{array}{l}0.021 * * \\
(2.65)\end{array}$ & $\begin{array}{l}0.015\left(^{*}\right) \\
(1.87)\end{array}$ & $\begin{array}{l}0.035^{*} \\
(2.30)\end{array}$ & $\begin{array}{l}19.534 \\
(1.43)\end{array}$ \\
\hline Share of own revenue & $\begin{array}{l}0.014 * * \\
(2.69)\end{array}$ & $\begin{array}{l}0.013^{*} \\
(2.97)\end{array}$ & $\begin{array}{l}0.019\left(^{*}\right) \\
(1.79)\end{array}$ & $\begin{array}{c}-4.070 \\
(0.46)\end{array}$ \\
\hline $\begin{array}{l}\text { Number of parties in the } \\
\text { executive }\end{array}$ & $\begin{array}{l}0.002 \\
(0.05)\end{array}$ & $\begin{array}{c}-0.001 \\
(0.04)\end{array}$ & $\begin{array}{c}-0.051 \\
(0.89)\end{array}$ & $\begin{array}{c}23.499 \\
(0.65)\end{array}$ \\
\hline $\begin{array}{l}\text { Share of leftist parties in } \\
\text { the parliament }\end{array}$ & $\begin{array}{l}-0.005 * * \\
(3.76)\end{array}$ & $\begin{array}{l}-0.005 * * \\
(3.63)\end{array}$ & $\begin{array}{l}-0.005(*) \\
(1.79)\end{array}$ & $\begin{array}{c}-1.245 \\
(0.57)\end{array}$ \\
\hline $\begin{array}{l}\text { Dummy for French and } \\
\text { Italian language }\end{array}$ & $\begin{array}{c}0.148 \\
(1.60)\end{array}$ & $\begin{array}{l}0.099 \\
(1.29)\end{array}$ & $\begin{array}{l}0.310\left(^{*}\right) \\
(1.85)\end{array}$ & $\begin{array}{c}143.231 \\
(1.36)\end{array}$ \\
\hline Dummy for canton Zug & $\begin{array}{c}0.070 \\
(1.02)\end{array}$ & $\begin{array}{c}0.088 \\
(1.40)\end{array}$ & $\begin{array}{c}-0.566^{* *} \\
(2.39)\end{array}$ & $\begin{array}{c}-105.534 \\
(0.93)\end{array}$ \\
\hline Constant & $7.041 * *$ & $6.962 * *$ & $9.722^{* *}$ & 154.517 \\
\hline $\bar{R}^{2}$ & 0.404 & 0.408 & 0.183 & 0.031 \\
\hline SER & 0.248 & 0.228 & 0.480 & 385.022 \\
\hline Chow test $(\hat{F})$ & $1.931\left(^{*}\right)$ & 1.459 & 1.489 & 0.864 \\
\hline Jarque-Bera & 1.260 & 1.957 & 1.303 & 0.324 \\
\hline
\end{tabular}

Notes: See Table 2 for notes. T-stats based on white heteroscedastic consistent standard errors. The expenditure, revenue and debt models are estimated in logarithms. Deficits are in absolute values. Estimates were performed with EViews, Version 3.1. The data set consists of 132 observations on Swiss local communities.

we see that it is a quite large effect. Actually, the 9 local communities who are rated as having the strongest restrictions had a balanced budget on average in 1990, those 23 communities which had at least restrictions had a deficit of $\$ 21$ per capita; the remaining 114 communities without any such constraints had an average deficit of $\$ 77$ per capita. If nothing else, this provides another indication that such constraints have a real effect.

5.4.2. Results on the political and economic controls. Neither the number of parties in the executive nor the share of the non-German-speaking population has an impact in any of the four equations. But contrary to our expectations as well as to the results on the cantonal level, the share of leftist parties in the parliament has a quite 
sizeable negative impact that is statistically significant. The estimated coefficient indicates that it reduces public expenditure and revenue of the local community with the highest share of leftist parties (Birsfelden), compared to one of the several communities without any leftist party in their parliament, by more than $20 \%$. Finally, the dummy variable for the canton Zug has a significant impact only on public debt, which is, however, rather strong; local communities in Zug have, ceteris paribus, less than $60 \%$ of the public debt per capita than communities in other cantons.

Taxable income and the unemployment rate have the expected signs, but the coefficients are never significantly different from zero. Population increases the deficit implying, for example, that Zürich (the largest Swiss city with 365000 inhabitants) has, ceteris paribus, a debt that is about $\$ 308$ per capita higher than the deficit in Arosa, which is the smallest local community in our sample with only 2300 inhabitants.

The share of the young population has a significant negative and the share of the old population has a significant positive impact on expenditure and revenue. This might be mainly due to the fact that a high share of young people, ceteris paribus, reduces tax receipts of the community, while many of the old people are 'good' taxpayers. Thus, due to the simultaneous decision over local revenue and spending in the budgetary process these coefficients more strongly reflect the financing aspect of the budget than the demand for local public services. Finally, the share of own revenue of the local community has a significant positive impact on spending and revenue - that is, the higher the share of free grants from the higher federal levels, the lower is total public expenditure and revenue. This might reflect the fact that such grants are mainly given to 'poor' communities but that they are only partly filling the gap between 'poor' and 'rich' communities.

\section{A DISCUSSION OF THE EMPIRICAL RESULTS IN THE LIGHT OF EXISTING ESTIMATES}

According to the analysis in the previous sections, direct legislation in Switzerland is basically characterized by two features. First, public spending, revenue and debt are statistically different in a direct democracy than in representative democracies. Second, the fiscal referendum is associated with lower spending and revenue and with lower public debt. Hence, Hypothesis 1 must be rejected; there are significant differences between jurisdictions with and without instruments of direct democracy. In other words, referenda and initiatives matter - they are not simply institutional veils. In addition our results indicate that fiscal referenda have teeth. Spending, revenue and public debt are lower if fiscal referenda exist and as such Hypothesis la cannot be rejected. How do these results compare to others in the literature? And how efficient are these economic policy outcomes in more general terms?

Systematic analyses of the impact of referenda and initiatives on economic policy are available for Switzerland and for the US states. ${ }^{13}$ For the US states Matsusaka (1995)

${ }^{13}$ For more detail, see Kirchgässner et al. (1999) and Feld and Kirchgässner (2000). 
provides the most convincing evidence. He reports that spending per capita per year of states with initiatives was $\$ 55-110$ lower (on average about 4\%) depending on the signature requirement for the initiative. With a signature requirement of $10 \%$ of the population, the impact of the initiative on spending becomes insignificant. For the period before the Second World War, Matsusaka (2000) finds, however, higher public spending in initiative states in a similar research design as in his previous study. The conclusion the author provides for these differences in his results for both time periods is that the antispending impact of initiatives is not a certain policy outcome. Initiatives serve citizens as instruments to correct policy outcomes in the direction of their preferences if they deviate from them. If citizens are more liberal (in the American sense) than representatives, this leads to higher spending in states in which an initiative is available. If voters are more conservative than representatives, they reduce government spending by the initiative. Interestingly enough, centralization of spending was reduced in the US states with initiatives: state spending was less than local spending in those states. Since local spending is closer to citizens than state spending and enables them to control spending more strongly, this evidence supports the conjecture that spending outcomes come closer to citizens' preferences in states with initiatives.

According to the results of more recent studies, Swiss citizens seem to be more fiscally conservative than their US counterpart. Feld and Kirchgässner (1999) report that those cities with budgetary referenda out of a sample of 131 large Swiss cities in 1990 spent $14 \%$ less than the cities without such a referendum. These results and those of Feld and Matsusaka (2000a) for the 26 Swiss cantons during the period 1986-97 are more or less in line with the estimates presented in this paper. More importantly, the significant differences in the spending model between cantons with and without fiscal referenda lend indirect support to the hypothesis that the fiscal referendum corrects spending outcomes towards the preferences of the median voter. The possibility to deviate from voters' preferences might give incentives to representatives either to spend too much or too little.

While there are also mixed results for revenue of US states for the two periods studied by Matsusaka, the results for Swiss cantons and cities is quite strong. Our estimates indicate that cantonal (net) revenue per capita is significantly lower in cantons and cities with fiscal referenda. Quantitatively, the impact is also non-negligible: it is $11 \%$ lower in the cantonal case and 20\% lower in the case of the cities. According to Feld and Kirchgässner (1999) the cities had, however, a revenue share from taxes and user charges, as opposed to transfers and subsidies from other government levels, that was $5 \%$ higher, and they levied an income tax on the median income that was $14 \%$ higher. In addition, the US states with initiatives and the cantons rely more on user charges than on broad-based taxes (for more detail, see Matsusaka, 1995 for US states and Feld and Matsusaka, 2000b for Swiss cantons).

Direct democratic cities in Switzerland also have lower public debt. Feld and Kirchgässner (1999) simulate that those cities where the citizens have no direct rights with respect to budgetary decisions, public debt per capita would, ceteris paribus, have 
been about $\$ 5600$ and thus $45 \%$ lower in 1990 than if these cities had had a direct democratic organization. ${ }^{14}$ These results are again corroborated by the estimates presented in this paper. Local public debt is reduced by $\$ 2464$ per capita. The cantonal estimates are, however, less convincing. There is no significant difference in public debt between cantons with and without fiscal referenda, while budget deficits of the cantons with fiscal referenda are even significantly higher than those of cantons without fiscal referenda. Similar results as in the Swiss local case can again be obtained for US states. Kiewiet and Szakaly (1996) provide evidence that states with a referendum on new bonds had a guaranteed debt per capita between 1961 and 1990 that was 33\% lower.

All in all, the evidence with respect to public spending, revenue, deficit and debt suggests that citizens demand fewer public services and seem to follow a sounder fiscal policy in systems with direct legislation than in parliamentary democracies. This results in a lower public debt per capita under direct democracy. Thus, a referendum democracy appears to fit Wicksell's (1896) idea of a link between the tax price and public services better than a purely parliamentary system. The question remains, however, whether the lower level of public spending also leads to a more efficient public sector. Very few studies attempt to investigate this question. Pommerehne (1983) analysed costs and prices of local garbage collection in 103 Swiss cities in 1970. He found that in cities with representative democracy the costs of private garbage collection were, ceteris paribus, about 20\% higher than in direct democracies. This provides some evidence that direct legislation enhances the technical efficiency of the public sector. Together with the results on budgetary policy, this is evidence in favour of the hypothesis that direct legislation in Switzerland results in less leeway of representatives to pursue their own interests, although these results should not be stressed too much.

Pommerehne and Weck-Hannemann (1996) derive interesting results with respect to tax morale. They present evidence that tax evasion is lower in those Swiss cantons in which citizens have an impact on budgetary policy in direct legislation. Using data for the years 1965, 1970 and 1978, they show that in those cantons tax evasion is, ceteris paribus, about $\$ 840$ lower as compared to the average of the cantons without such direct influence. ${ }^{15}$ If, however, the willingness to pay taxes is the higher the more satisfied citizens are with public services supplied, then these results are evidence for a higher satisfaction of citizens and, therefore, for greater efficiency of the provision of public services.

These studies lend support for the hypothesis that direct democratic systems are more efficient than representative democratic ones. A more efficient political system should also lead to better economic performance. Feld and Savioz (1997) study the relationship between budgetary referenda and economic performance of Swiss cantons measured by

\footnotetext{
${ }^{14}$ Excluding Zurich, as an outlier with an extremely high debt, the simulated difference was still $\$ 2520$ or $24 \%$, respectively. Neither formal fiscal restraints, nor a budgetary process with a strong role of the mayor or the secretary of finance, succeed in putting such a strong constraint on debt issuing.

${ }^{15}$ There are also theoretical arguments why citizens in direct democracies evade taxes to a lesser extent than those in representative democracies. See Pommerehne, Hart and Feld (1997).
} 
GDP per employee. In a panel with annual data from 1984 to 1993 for the 26 Swiss cantons, they arrive at the conclusion that GDP per employee is, ceteris paribus, about $5 \%$ higher in those cantons with budgetary referenda compared to cantons without those referenda. Again there is corroborating evidence for the US states. Blomberg and Hess (2000) report that states with initiatives converged with a growth rate that was 3 percentage points higher than their companion states with no initiative during the period 1969 to 1986. Finally, Frey and Stutzer (2000) even present evidence that people in Switzerland perceive themselves as more satisfied with their life as a whole in direct democratic cantons keeping income levels and other controls constant.

Summarizing the evidence presented in this paper and bringing them into broader perspective with additional existing evidence, a relatively uncontested result obtains elements of direct democracy are associated with lower public expenditure, revenue and public debt, with a higher efficiency of the public sector in terms of cost of providing public services and collecting tax revenue, with better economic performance and with higher satisfaction of citizens. These results lead us to the conclusion that direct democracy is a more efficient way of governing public finance at the state and local level than a purely representative system.

\section{POLICY IMPLICATIONS AND CONCLUDING REMARKS}

This paper discusses theoretical arguments as to why referenda and initiatives force governments to adopt policies that are closer to citizens' preferences. Quite simply, citizens in a representative democracy that have access to instruments of direct democracy have the ability to control their representatives more effectively than citizens in a purely representative democracy. A referendum enables them to correct policy outcomes developed by the government or the parliament, while the initiative serves as a means to create policies that are fully neglected by the political establishment. To put substance to the theoretical arguments, we present evidence on Swiss fiscal outcomes at the cantonal and local levels. This evidence shows that significant differences in fiscal outcomes obtain in jurisdictions with and without fiscal referenda. In particular, the fiscal referendum in Switzerland results in lower spending, lower revenue and local public debt. A fiscal referendum of the form used in Switzerland obviously matters. Moreover, additional evidence from the literature (discussed at the end of the previous section) supports the hypothesis that policy outcomes are more efficient in direct than in representative democracies. Although some questions remain to be addressed by future research, we conclude that the introduction of fiscal referenda would improve budgetary procedures in local and regional governments that have purely parliamentary forms of democratic representation.

This also holds in the case of the state and local levels of member countries of the European Union. Although we do not think that the Swiss system can be adopted one for one, we are not aware of convincing reasons why the sub-central levels should be basically organized in a different way in other countries. Certainly, the strong fiscal federalism in Switzerland is promoting the effectiveness of direct democracy in 
Switzerland as well. Thus, the impact of referenda and initiatives on fiscal policy outcomes in countries with less independent decision-making power of sub-federal jurisdictions may be reduced, but it should not lead in an opposite direction.

By considering a reform towards more direct democracy, some important characteristics of fiscal referenda in Switzerland have to be mentioned. Like in many Swiss cantons, with respect to spending projects, it would be useful to specify a spending threshold above which new projects or new funds have to be decided by a fiscal referendum. The Swiss experience shows that such a procedure has teeth and entails representatives to conduct sound fiscal policies. At the Swiss central level policy-makers aim at introducing an optional fiscal referendum on new projects as well. If the Swiss federal level is able to learn from the cantons, why should EU member states not be able to learn something for the governance of their sub-federal jurisdictions?

\section{Discussion}

\section{Kai Konrad}

\section{WZB and Freie Universität Berlin}

Europe and many other areas are in the middle of a process of redesigning their political structure, including their decision-making procedures. A contribution that sheds light on the effects of an important decision-making principle, such as direct democracy, should be particularly welcome. The Feld-Kirchgässner paper shows that political entities in Switzerland that have strong elements of direct voting tend to impose lower tax burdens, have lower public spending, and keep their budgets more balanced, both in the short run and in the long run. The authors claim that there is a causal relationship between referenda and expenditure discipline.

Establishing a causal relationship empirically, however, is a difficult matter. Referenda and sound fiscal policy are associated in the data, but this might be because a preference for referenda voting and a preference to sound fiscal policy are both caused by a third factor - for example, the conservativeness of a region's voters. One could test for this in the Swiss case using information on cantonal and local voting patterns in national referenda on questions such as female voting rights, and the autonomy of regions and cantons within the Swiss federation. The failure of the authors to check this is a shortcoming of the paper.

On theoretical grounds, referenda are likely to matter, as the authors argue, but this need not automatically produce stronger fiscal discipline. For instance, given the usual shape of income distributions, median voters are likely to favour redistribution policies. This suggests that if - as the authors assume - the decisive referenda voter is the median voter, referenda should generate a tendency for more redistribution (whether the decisive voter in referenda is the median voter is a separate issue that I do not have space to go into here). Moreover, referenda might affect the type as well as the level of spending. 
Another theoretical point concerns welfare. The paper seems to view anything that brings politics closer to the median voter position as good. This is not clear. First, median voter outcomes are typically inefficient compared to systems that allow winners to compensate losers. Representative democracy and the lobbying process have been advocated since they bring various groups' willingness-to-pay into this process and may potentially improve efficiency. Second, if the voters' preferences are sufficiently dispersed, the spectrum of Pareto efficient policies is very broad, so Pareto inefficient outcomes under any of the regimes are unlikely to occur, at least in a static context. ${ }^{16}$ Finally, the theoretical analysis is limited in that it neglects dynamic aspects like time consistency $^{17}$ and issues like the ability to commit on a policy that is ex ante beneficial but not desirable from an ex post point of view, and they neglect the information cost in the two types of regimes.

\section{Thierry Verdier}

\section{DELTA, Paris}

This paper aims to study the influence of political institutions on the level of fiscal revenues, expenditures and public debt. The basic approach is to see if direct democracy (through referenda and initiatives) implies fiscal policy outcomes that are different (and maybe better) from those generated by representative democracy. This is done by investigating the impact of direct democracy on fiscal behavior in Swiss cantons and local communities. From the conceptual point of view, the motivation is to see whether institutions matter - that is, they are more than 'veils' dressing up rational decisions that would be taken by voters and politicians under any circumstances. Taking a policy perspective, this exercise should indicate which institutional framework (direct or representative democracy) is best able to reflect the distribution of preferences of voters on policy issues. For both reasons, this paper is interesting and much welcome.

After reading the paper, I am quite convinced by the idea that direct legislation is by no means the same as representative democracy. On the other hand, I am a bit less enthusiastic than the authors on the relative advantages of direct legislation. Let me start first with the conceptual aspects.

The authors present a rather clear theoretical discussion of why referenda and initiatives may affect budgetary policy, and in this the authors reveal a predilection for direct legislation. I am a bit less enthusiastic on the matter. For instance, I am not sure that the informational issues have been given the attention they deserve. Information is a public good, so the free rider problem of acquiring information will be even more acute for the average citizen than for the average politician who, as a professional, has more direct stakes in the issues and the decisions. This is important since imperfect information

\footnotetext{
${ }^{16}$ Inefficiency in a representative democracy can occur in a dynamic context. See, e.g., Glazer et al. (1998) due to strategic commitment, whereas ex post opportunistic decision-making may be more likely to occur under referenda voting.

${ }^{17}$ For instance, Glazer and Konrad (1993) consider policy choice that takes into account how a policy changes the probability for a decisive group to stay decisive. Referendum voting and representative democracy would certainly behave differently under this perspective.
} 
problems reduce the scope for the beneficial role of direct legislation to constrain politicians. Some other aspects of direct legislation versus representative democracy seem also to be missing in the discussion. First, there is the beneficial role of commitment of delegation and representative institutions. This is the idea that 'giving too much voice to the people' may induce populism and shortsighted behaviour. Formally, if the median voter has intertemporal inconsistency problems (protection of minority groups, capital taxation, monetary policy), then actually allowing referenda and initiatives may provide outcomes that may be worse than what would have been obtained through delegated politics. There is also the idea of 'referenda fatigue'. Citizen participation may drop over time, raising questions about how representative referendum-voters are all citizen's preferences.

Getting now to the empirical part of the paper, the authors show quite convincingly that there is a significant difference between 'direct legislation' and representative democracy concerning fiscal behaviour, and that mandatory referenda reduce public expenditures and public revenues. The deficits and public debt results, however, are less convincing. First, there may be an endogeneity problem (between public debt and cantonal or local GDP) for the public debt equation. Second, at the cantonal level, referenda do not affect debt and seem to increase public deficits. On the contrary, fiscal referenda seem to negatively affect public debt at the local level. Interestingly, the effect of fiscal restraint on debt and public deficits is just the opposite - a strong negative impact on public debt and deficit at the cantonal level and no effect at the local level. To me, this suggests that referenda seem to be quite effective at containing public debt and deficits at the local level, but they are less effective at the higher level. In that case, formal fiscal restraints (rather than direct democracy) do a better job.

Finally, there is the puzzling 'wrong sign' of the signature requirement for statutory initiatives in the 'common' and 'direct democracies' cantonal equation, which turns out to be the 'right sign' in the 'representative democracies' equation. One way to interpret this, which is consistent with Matsusaka (2000), is to say that citizens use initiatives to make spending policy closer to their preferred point. In cantons where fiscal referenda can already limit the amount of public spending, the use of initiatives is to stimulate public projects which would not have been proposed by politicians and therefore to increase expenditures. On the other hand, in cantons without fiscal referenda, citizens use the instrument of initiatives to limit public spending.

\section{Panel discussion}

Andy Rose, referring to the California experience, pointed out that referenda might be driven too much by special interest groups. Richard Baldwin added that it would be interesting to see the participation rates in the referendums. He suggested that the timecosts of voting are large, and particularly binding for young people and working people. If 
this biases participation in referenda toward rural people and old people, the outcomes might be biased in a conservative direction. Benny Moldovanu doubted that a referendum can address more than one issue at a time and may therefore not be efficient. In order to find compromises, it is necessary to talk about several issues at the same time. Multidimensional problems are often reduced to only one dimension. Jan van Ours criticized the authors for relying on cross-section evidence only (in the case of the local community regressions). Even though there is little time variation in the data, it might still be useful since there are many differences in the cross-section that may not be controlled for.

Gebhard Kirchgässner responded that the participation rate is little bit above $40 \%$ on the average in Switzerland, but sometimes as high as $75 \%$. He suggested that this was not that low in comparison to, for example, presidential elections in other countries. Further Kirchgässner noted that people often say that the Swiss political culture is unique and thus Swiss results cannot be applied to other nations. He argued, however, that once the political institutions have changed, the political culture might change as well in other countries. If the institutions do not exist, this political culture cannot evolve.

\section{REFERENCES}

Besley, T. and S. Coate (1997). 'An economic model of representative democracy', Quarterly Fournal of Economics, 112, 85-114.

Blankart, G.B. (2000). 'The process of government centralization: A constitutional view', Constitutional Political Economy, 11, 27-39.

Blomberg, S.B. and G.D. Hess (2000). 'The impact of voter activity on economic activity', mimeo, Wellesley College, 2000.

Butler, D. and A. Ranney (1994). Referendums around the World, Macmillan, Basingstoke.

Drèze, J. (1993). 'Regions of Europe: A feasible status, to be discussed', Economic Policy, 17, $266-307$.

Feld, L.P. and G. Kirchgässner (1999). 'Public debt and budgetary procedures: Top down or bottom up? Some evidence from Swiss municipalities', in J.M. Poterba and J. von Hagen (eds.), Fiscal Institutions and Fiscal Performance, Chicago University Press and NBER, Chicago, 15-179.

- (2000). 'Direct democracy, political culture and the outcome of economic policy: A report on the Swiss experience', European Fournal of Political Economy, 16, 287-306.

Feld, L.P. and J.G. Matsusaka (2000a). 'Budget referendums and government spending: Evidence from Swiss cantons', mimeo, University of St Gallen.

(2000b). 'The political economy of tax structure: Some panel evidence for Swiss cantons', mimeo, University of St Gallen.

Feld, L.P. and M.R. Savioz (1997). 'Direct democracy matters for economic performance: An empirical investigation', Kyklos, 50, 507-538.

Feld, L.P. and F. Schneider (2001). 'State and local taxation', forthcoming in N.J. Smelser and P.B. Baltes (eds.), International Encyclopaedia of the Social and Behavioral Sciences, Elsevier, Oxford.

Frey, B.S. and A. Stutzer (2000). 'Happiness, economy and institutions', Economic Fournal, 110, 918-938.

Gerber, E.R. (1996a). 'Legislative response to the threat of initiatives', American Journal of Political Science, 40, 99-128.

- (1996b). 'Legislatures, initiatives, and representation: The effects of state legislative institutions on policy', Political Research Quarterly, 49, 263-286.

- (1999). The Populist Paradox: Interest Group Influence and the Promise of Direct Legislation, Princeton University Press, Princeton.

Glazer, A., M. Gradstein and K.A. Konrad (1993). 'The evaluation of risky projects by voters', Fournal of Public Economics, 52.

Glazer, A. and K.A. Konrad (1998). 'The electoral politics of extreme policies', Economic Fournal, 108. 
Greene, W.H. (1998). LIMDEP Version 7.0: User's Manual, Econometric Software, Inc., Plainview.

Haan, J. de and J.-E. Sturm (1994). 'Political and institutional determinants of fiscal policy in the European Community', Public Choice, 80, 157-172.

Heussner, H.K. (1999). 'Ein Jahrhundert Volksgesetzgebung in den USA', in H.K. Heussner and O. Jung (eds.), Mehr direkte Demokratie wagen, Olzog, Munich, 101-122.

Heussner, H.K. and O. Jung (eds.) (1999). Mehr direkte Demokratie wagen, Olzog, Munich.

Kessler, A. (2001). 'Representative versus direct democracy: The role of informational asymmetries', Public Choice, forthcoming.

Kiewiet, D.R. and K. Szakaly (1996). 'Constitutional limitations on borrowing: An analysis of state bonded indebtedness', Journal of Law, Economics and Organization, 12, 62-97.

Kirchgässner, G., L.P. Feld and M.R. Savioz (1999). Die direkte Demokratie: Modern, erfolgreich, entwicklungs- und exportfähig, Helbing and Lichtenhahn, Basel.

Longchamp, C. (1991). 'Herausgeforderte demokratische Öffentlichkeit: Zu den Möglichkeiten und Grenzen des politischen Marketings bei Abstimmungen und Wahlen in der Schweiz', Schweizerisches Fahrbuch für Politische Wissenschaft, 31, 303-326.

Marchand, M.-J. (1999). L'économie de la décentralisation: Un enjeu financier pour les collectivités locales, Didact économie, Rennes.

Marino, A.M. and J.G. Matsusaka (2000). 'Decision processes, agency problems, and information: An economic analysis of budget procedures', mimeo, University of Southern California, Los Angeles.

Matsusaka, J.G. (1992). 'Economics of direct legislation', Quarterly fournal of Economics, 107, $541-571$.

- (1995). 'Fiscal effects of the voter initiative: Evidence from the last 30 years', fournal of Political Economy, 103, 587-623.

- (2000). 'Fiscal effects of the voter initiative in the first half of the twentieth century', fournal of Law and Economics, 43, 619-650.

Matsusaka, J.G. and N.M. McCarty (1998). 'Political resource allocations: The benefits and costs of voter initiatives', unpublished manuscript, University of Southern California, Los Angeles.

Müntefering, F. (2000). 'Demokratie braucht Partei', www.spd.de/events/demokratie/fm.htm, 5 April 2000.

Muzellec, R. (1994). Finances locales, Dalloz, Paris.

NZZ (2000). Statistisches Fahrbuch der Schweiz 2000, Zürich.

Peltzman, S. (1992). 'Voters as fiscal conservatives', Quarterly Fournal of Economics, 107, 327-361.

Pommerehne, W.W. (1978). 'Institutional approaches to public expenditure: Empirical evidence from Swiss municipalities', Journal of Public Economics, 9, 255-280.

— (1983). 'Private versus öffentliche Müllabfuhr - nochmals betrachtet', Finanzarchiv, 41, $466-475$.

Pommerehne, W.W. and H. Weck-Hannemann (1996). 'Tax rates, tax administration and income tax evasion in Switzerland', Public Choice, 88, 161-170.

Pommerehne, W.W., A. Hart and L.P. Feld (1997). 'Steuerhinterziehung und ihre Kontrolle in unterschiedlichen politischen Systemen', Homo oeconomicus, 14, 469-487.

Romer, Th. and H. Rosenthal (1979). 'Bureaucrats versus voters: On the political economy of resource allocation by direct democracies', Quarterly Foumal of Economics, 93, 563-587.

Roubini, N. and J.D. Sachs (1989). 'Political and economic determinants of budget deficits in the industrial democracies', European Economic Review, 33, 903-938.

Stauffer, Th.P. (2001). Instrumente des Haushaltsausgleichs: Ökonomische Analyse und rechtliche Umsetzung, $\mathrm{PhD}$ thesis, University of St Gallen.

Steunenberg, B. (1992). 'Referendum, initiative and veto power: Budgetary decision-making in local government', Kyklos, 45, 501-529.

Trechsel, A. and U. Serdült (1999). Kaleidoskop Volksrechte: Die Institutionen der direkten Demokratie in den schweizerischen Kantonen 1970-1996, Helbing and Lichtenhahn, Basel.

Weingast, B.R., K.A. Shepsle and C. Johnsen (1981). 'The political economy of benefits and costs: A neoclassical approach to distributive politics', Journal of Political Economy, 89, 642-664.

White, St. and R.J. Hill (1996). 'Russia, the Former Soviet Union and Eastern Europe: The referendum as a flexible political instrument', in M. Gallagher and P.V. Uleri (eds.), The Referendum Experience in Europe, Routledge, London, 153-170.

Wicksell, K. (1896). Finanztheoretische Untersuchungen nebst Darstellung und Kritik des Steuerwesens Schwedens, Gustav Fischer, Jena. 